\title{
Middle Miocene drowned ramp in the vicinity of Marija Bistrica (Northern Croatia)
}

The Mining-Geology-Petroleum Engineering Bulletin UDC: $56: 551.8$

DOI: $10.17794 / \operatorname{rgn} .2018 .4 \cdot 3$

Original scientific paper

\author{
Jasenka Sremac'; Kristina Tripalo'; Marko Repac²; Marija Bošnjak3; Davor Vrsaljko; \\ Tihomir Marjanac'; Alan Moro' ${ }^{1}$; Borna Lužar-Oberiter' ${ }^{1}$ Karmen Fio Firi' ${ }^{1}$ \& Šimun Aščić ${ }^{1}$ \\ ${ }^{1}$ Department of Geology, Faculty of Science, University of Zagreb, Horvatovac 102 a, 10000 Zagreb, professors and a student \\ ${ }^{2}$ Faculty of Mining, Geology and Petroleum Engineering, University of Zagreb, Pierottijeva 6, 10000 Zagreb, student \\ ${ }^{3}$ Croatian Natural History Museum, Demetrova 1, 10000 Zagreb, curators
}

\begin{abstract}
Fossiliferous Middle Miocene deposits from the surroundings of Marija Bistrica (north-east of Zagreb) transgressively overly older pre-Cenozoic bedrocks. Fossils from shallow marine environments are in most cases preserved as bioclasts, while deep marine calcareous oozes characterize the pelagic marls. The age of the transgressive sequence is estimated on the basis of planktic biota from marls (foraminifera, nannoplankton and pteropods) as the Badenian NN5 Nannozone. The following palaeoenvironments can be distinguished or presumed on the basis of biota and sedimentary features: (1) beach characterized by polymictic conglomerates with rhodolith-rich carbonate matrix; (2) oyster banks, recognized from secondarily found oyster clusters; (3) lagoons marked with compact bioclastic deposits and rhodolith-halimeda assemblage; (4) patch-reefs recognized from the surrounding bioclastic deposits; (5) shallow subtidal mäerl beds preserved as loose bioclastic deposits and (6) distal slope argillaceous marls with pelagic biota. Palaeoenvironmental analyses indicate rapid drowning, most probably corresponding to the transgression during the Middle Badenian TB 2.43 rd order transgressive-regressive sequence.
\end{abstract}

Keywords:

Langhian, transgression, palaeoenvironment, biostratigraphy, Medvednica Mt.

\section{Introduction}

The area of Southern and South-East Europe during the Miocene epoch survived a variety of stress events triggered by a combination of intense tectonics and global climate changes (Cloetingh et al., 2005; Pavelić, 2005; Kováč et al., 2007, 2017 and references therein; Tomljenović et al., 2008; Malvić and Velić, 2011; Matenco and Radivojević, 2012; Horváth et al., 2015; Balázs et al., 2016; Pavelić and Kovačić, 2018). The Middle Miocene Climatic Optimum (approximately between 18 and $14 \mathrm{Ma}$ ) caused the global highstand and flourishing of marine life, while the forthcoming cooling, followed by the growth of ice sheets, led to an extinction wave of terrestrial and aquatic biota (Shackleton and Kennett, 1975; Zachos et al., 2001; Ivanov et al., 2002; Böhme, 2003; Pekar and DeConto, 2006; Holbourn et al., 2007 and references therein; Herold et al., 2011). All these factors particularly influenced areas along the European collision zones as well as those situated along the shores of the Miocene oceans and seas, including the shores of the Paratethys Sea (Rögl

Corresponding author: Jasenka Sremac

jsremac@geol.pmf.hr
1998, 1999; Hudáčková et al., 2000; Harzhauser and Piller, 2007; Piller et al., 2007; Kováč et al., 2007, 2017).

One such realm is the territory of today's Northern Croatia, whose plains and depressions among the uplifted mountain chains were flooded by the Paratethys Sea, palaeographically marking its southwestern margin and forming the Pannonian Basin System (PBS) (Pavelić, 2001, 2005; Vrsaljko et al., 2006; Kováč et al., 2007, 2017; Ćorić et al., 2009; Sremac et al., 2016; Pezelj et al., 2016; Bošnjak et al., 2017; Pavelić and Kovačić, 2018) (see Figure 1).

Several authors discussed the number (two or three) and timing of the Badenian marine transgressions (e.g. Rögl, 1998, 1999; Harzhauser and Piller, 2007; Kováč et al., 2007; Piller et al., 2007; Rögl et al., 2007; Pezelj et al., 2016; Bošnjak et al., 2017 and references therein; Pavelić and Kovačić, 2018). Erosional processes during the emersions and early phases of superimposed transgressions destroyed or camouflaged evidence of previous transgressive-regressive sequences (Rögl et al., 2007). Nevertheless, all authors correlate the youngest Badenian transgressive-regressive sequence with the Late Badenian TB 2.5 3rd order sequence (within the NN6 Nannozone) (e.g. Haq et al., 1988; Hardenbol et 
al., 1998; Kováč et al., 2007; Rögl et al., 2007; Hohenegger et al., 2014; Pavelić and Kovačić, 2018).

The aim of this study is to determine the age and palaeoenvironments of the studied deposits, and to prove the existence of the older TB 2.4 transgressive-regressive sequence, which biostratigraphically corresponds to the NN5 Nannozone, in the studied area.

\section{Geological setting}

The research area during the Miocene period belonged to the rift-type North Croatian Basin (NCB), situated at the south-western margin of the Neogene Pannonian Basin within the Central Paratethys realm. Its development can be divided into two successive phases: Early to Middle Miocene syn-rift phase characterized by extensional subsidence and Middle Miocene to Quaternary post-rift phase characterized with thermal subsidence (Pavelić and Kovačić, 2018 and references therein).

The uplifted structure known today as Medvednica Mt. (see Figures 1, 2, 3a) already represented an uplifted terrain during the Middle Miocene (Pavelić, 2001; Avanić et al., 2003; Vrsaljko et al., 2006; Tomljenović et al., 2008 and references therein), strongly affected by a combination of tectonic movements and climate driven transgressive-regressive sequences sensu Haq et al. (1988) and Haq and Al-Qahtani (2005).

Miocene transgressive successions in the area of Mt. Medvednica were studied by several authors (e.g. Gorjanović-Kramberger, 1908; Kranjec et al., 1973; Šikić et al., 1978, 1979; Basch, 1981, 1983; Tomljenović, 2002; Vrsaljko et al., 2006; Ćorić et al., 2009; Velić and Vlahović, 2009; Brlek et al., 2016; Bošnjak et al., 2017; Pezelj et al., 2017). Underlying bedrocks can be of various age (in most cases Palaeozoic, Triassic or Cretaceous), and transgressive sequences exhibit di- verse features, depending on the palaeo-relief and transgression dynamics. Different transgressive-regressive sequences have been determined in the Badenian sediments of Medvednica Mt. The second Badenian sequence TB 2.4, within the NN5 Nannozone, is defined in the central part of the Medvednica Mt. (Čučerje area) by several authors (e.g. Kochansky, 1944; Avanić, 1997; Ćorić et al., 2009; Pezelj, 2015; Bošnjak et al., 2017), and presumed in the north-eastern part (Marija Bistrica and Orešje area) by Brlek et al. (2016) and Bošnjak (2017). The youngest Badenian transgressive-regressive sequence TB 2.5, within the NN6 Nannozone, is recorded in a wide area of Medvednica Mt.; in the southwestern part (Dolje area) by various authors (e.g. Vrsaljko et al., 2006; Bošnjak et al., 2014; Pezelj et al., 2016), in the central part (Čučerje area) by e.g. Pezelj et al. (2007), and in the north-eastern area (Marija Bistrica and Orešje area) by e.g. Vrsaljko et al. (2006), Pezelj and Sremac (2010), Brlek et al. (2016) and Pezelj et al. (2017).

After the publication of the Basic geological map of this area (Šikić et al., 1978, 1979; Basch, 1981, 1983) in 1998, new Middle Miocene outcrops, including the studied section, were exposed along the road AdamovecMarija Bistrica (see Figures 2 and 3).

\section{Materials and methods}

\subsection{Field work}

Sampling along the road Marija Bistrica-Adamovec in the north-eastern part of Medvednica Mt. (see Figure 3) took place during 2015, 2016 and 2017. The Middle Miocene deposits crop out along the road between $45^{\circ} 58^{\prime} 54.04^{\prime \prime} \mathrm{N} 16^{\circ} 6^{\prime} 53.56^{\prime \prime} \mathrm{E}$ and $45^{\circ} 58^{\prime} 58.27^{\prime \prime} \mathrm{N} 16^{\circ}$ 6'52.62'E, in a $60 \mathrm{~m}$ long succession (see Figure 3), but some parts of the outcrop are covered by soil and vegetation. Direct contact of Miocene basal conglomerates

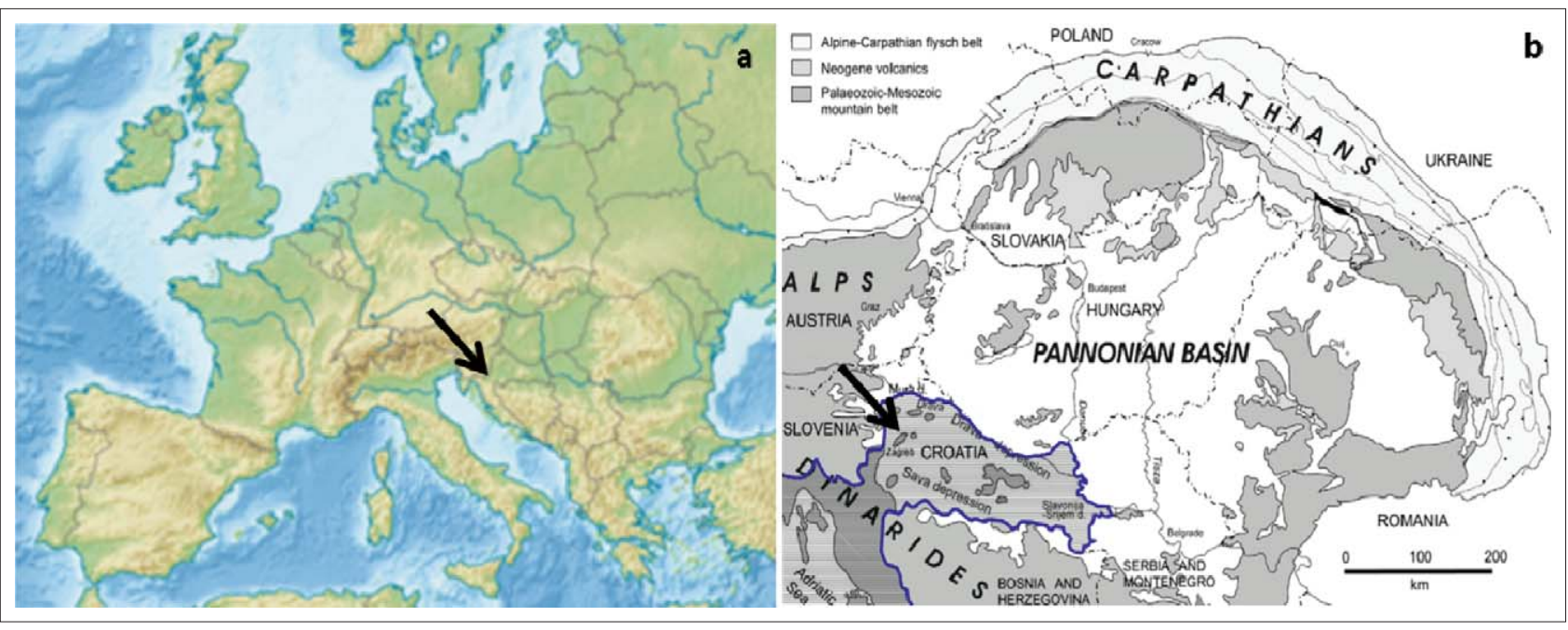

Figure 1: Geographic (a) and palaeogeographic (b) setting of the study area (palaeogeography after Kováč et al., 20o7; from http://www.azu.hr/en-us/E-P/Geological-overview-onshore) 


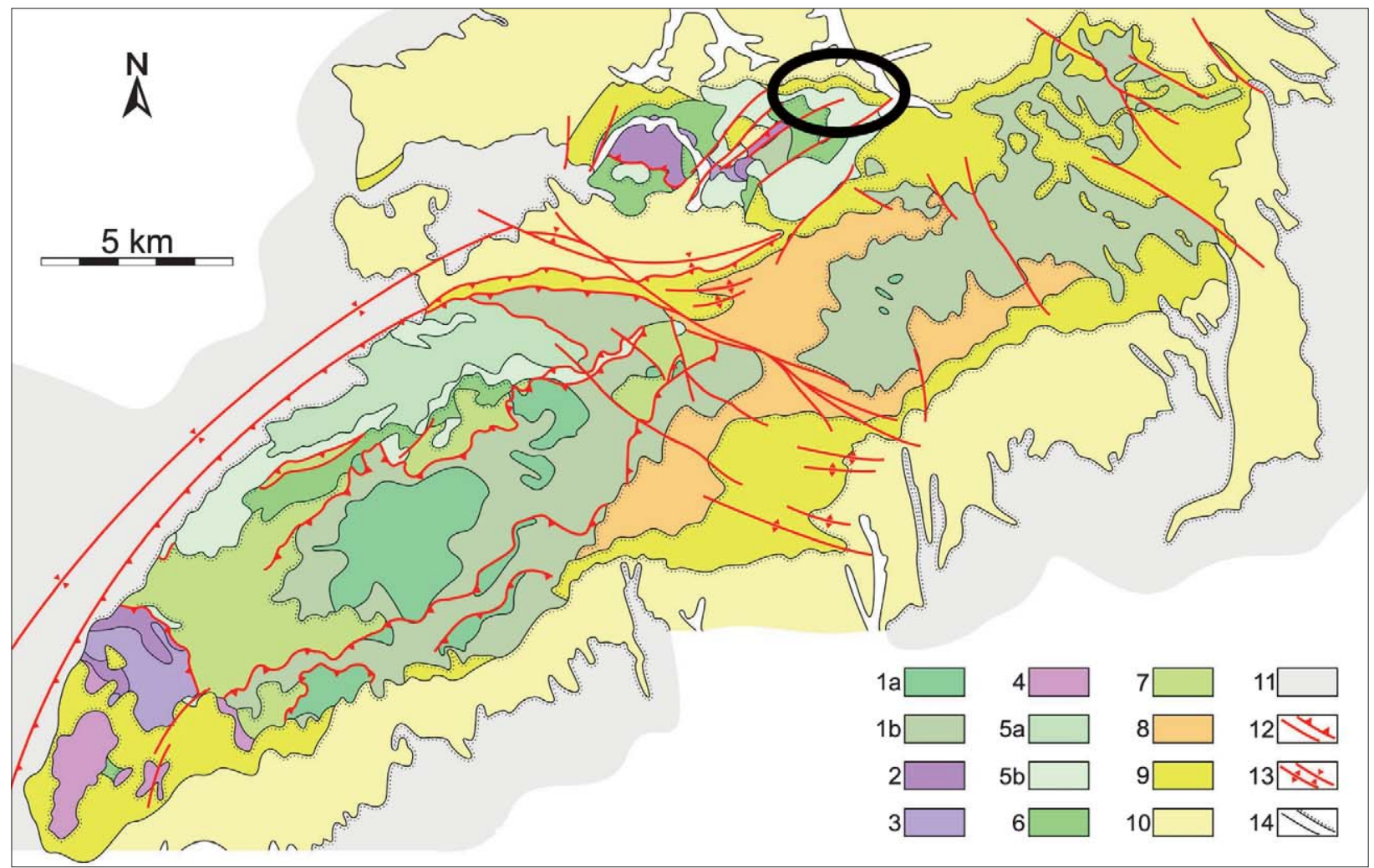

Figure 2: Geological map of Medvednica Mt. (after Tomljenović, 2002) with marked position of the study area. Legend: 1a - orthometamorphic deposits, mainly green schists, of Silurian to Upper Triassic low-grade metamorphic complex;

$\mathrm{lb}$ - Silurian to Upper Triassic parametamorphic deposits containing slates, phyllites, metapelites, metasandstones, metacarbonates and marbles; 2 - Lower Triassic sandstones, siltites, shales, ooid limestones and calcarenites; 3 - Middle Triassic dolomites with limestone, shale, chert and pyroclastic intercalations; 4 - Upper Triassic stromatolitic dolomites; 5a - Mesozoic ophiolitic complex with prevailing magmatic deposits (basalts, diabases, gabbros and peridotites); $5 \mathrm{~b}$ - Mesozoic ophiolites, containing mainly sedimentary deposits (shales, greywackes, radiolarites, conglomerates and limestones); 6 - Aptian to Cenomanian shallow-marine clastites and limestones, and deep-marine calcarenites, calcrudites and marls; 7 - Uppermost Cretaceous to Palaeocene fluvial and shallow-marine clastic deposits, reef limestones, micrites, and deep-marine calcarenites, calcrudites, siltites and marls; 8 - Lower Miocene fluvial deposits, lake clastites and limestones with coal intercalations (Ottnangian), and marine clastites and marls (Carpathian); 9 - Middle Miocene shallow-marine clastites, reef limestones, calcarenites and marls (Badenian), and brackish marls, limestones and clastites (Sarmatian);

10 - Upper Miocene brackish limestones, clastites, marls and clays (Pannonian), and marls and clastites with coal intercalations (Pontian); 11 - Pliocene and younger gravels, sands and clays; 12 - different types of faults; 13 -axis of anticlines and synclines; 14 - normal and transgressive boundaries.

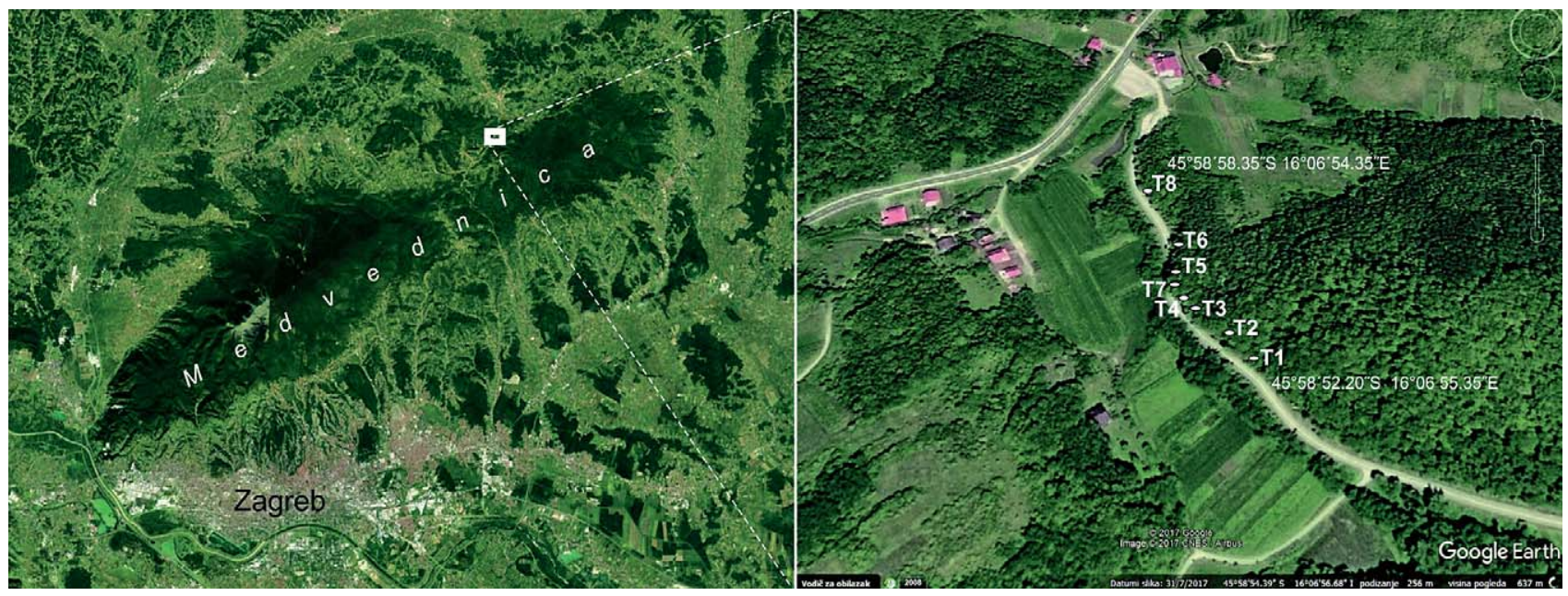

Figure 3: Geographic position of the study area on NE Medvednica Mt. (left); observation points (Stops T1-T8) of the Middle Miocene sequence exposed along the road Marija Bistrica-Adamovec (right); (Google Earth). 

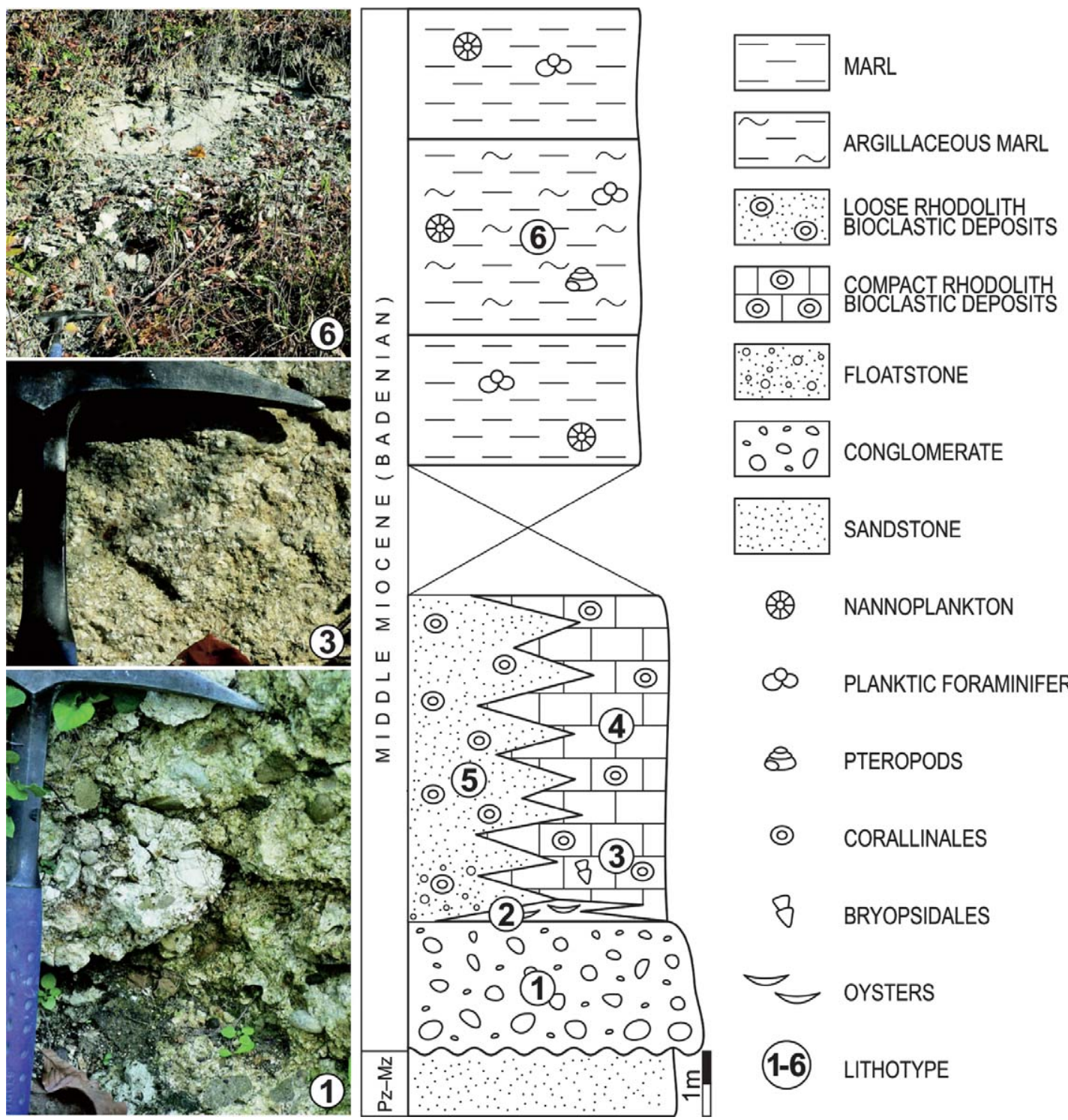

NANNOPLANKTON

@ PLANKTIC FORAMINIFERA

8 PTEROPODS

(?) CORALLINALES

8 BRYOPSIDALES

$\exists$ OYSTERS

(1-6) LITHOTYPE

Figure 4: Sedimentary log of the Miocene deposits in the vicinity of Marija Bistrica. Lithotypes: (1) basal conglomerates with rhodolith-rich calcarenite matrix; (2) oyster clusters; (3) compact bioclastic deposits with rhodolith-Halimeda assemblage; (4) compact bryozoan-rhodalgal-coral bioclastic deposits; (5) loose rhodolith-rich bioclastic deposits and (6) argillaceous marls with pelagic biota.

with bedrock (red sandstone) is visible at Stop T1, while contact of basal conglomerates with rhodolith deposits is exposed at T5. Bedding planes can be measured in marls, at Stops T7 and T8. Marls are dipping towards the west at an angle of $50-70^{\circ}$. As layers are oriented more or less parallel to the road, direct measuring of deposit thickness is not possible. A sedimentary log is partly reconstructed on the basis of superposition and measurable bed thickness at several stops along the road (see Figures $3 \mathrm{~b}$ and 4 ).

During the field work, macrofossils were collected for palaeontological analyses. Samples of rhodalgal deposits and conglomerates were taken for preparation of polished surfaces and thin sections. Visually different types of marls were sampled in the field and prepared for wet sieving.

\subsection{Laboratory work}

Laboratory work was performed in the laboratory of the Division of Geology and Palaeontology, Department of Geology, Faculty of Science in Zagreb.

Polished slabs were prepared from four samples of basal conglomerates to reveal the size, shape, composition and origin of the pebbles. Thin sections were prepared from pebbles and "Lithothamnion Limestone".

Marl samples from Stops T6 (1A, 1B) and T7 (2B), weighing ca. $0.3 \mathrm{~kg}$, were crushed into small pieces and soaked in water. After 24 hours, the material was washed out through a sieve system comprising $0.5,0.2,0.125$ and $0.63 \mathrm{~mm}$ sieves.

Selected planktic and benthic foraminiferal taxa were hand-picked for oxygen and carbon isotope analysis per- 
formed at the Institute of Earth Surface Dynamics, Lausanne, Switzerland.

Calcareous nannofossil probes were prepared by standard method of Bown and Young (1998). Suspended particles were separated by centrifuge; residue was spread onto glass slides, dried on a hot plate, covered by a cover slip and fixed using Canada balsam.

\subsection{Photography}

Microfossil analyses were performed at the Department of Geology, University of Zagreb. Microfossils and microfacies were studied using an Olympus-SZX10 stereo-microscope and a Leica Laborlux 11 polarizing microscope, photographed by a Canon EOS 1100 camera and saved by a Quick PHOTO CAMERA 3.0 software.

Nannofossils were studied by a Zetoplan Reichert polarizing microscope and photographed by a Canon EOS 400D.

The collected macrofossils were cleaned and photographed using a CANON EOS 6D camera at the Croatian Natural History Museum.

\subsection{Collections}

Samples of basal conglomerates, polished slabs and thin sections are stored in the Division of Geology and
Palaeontology, Department of Geology, University of Zagreb (thin section temporary numbers MB.1, MB.2, MB.3 and MB.8a,b).

Bivalves are part of the Croatian Natural History Museum Collection (CNHM), with temporary numbers MB4-1, MB4-A4_1, MB7 and GR17.

\section{Palaeontological and isotope analyses}

\subsection{Nannoplankton}

A rich and diverse calcareous nannoplankton (coccolithophores) assemblage was extracted from grey and yellow marls collected at Stops T6 (1A, 1B) and T7 (2B) (see Table 1).

Nannofossil determinations were based upon PerchNielsen (1985), Bown (1998), Bartol (2009) and http:// ina.tmsoc.org/Nannotax3/index.php?dir $=$ Coccolithophores.

Coccolithophores are excellently preserved and represent $80-90 \%$ particles in each prepared probe. The most common species is Coccolithus pelagicus, representing almost half of the determined specimens. Genus Calcidiscus, with three species (see Table 1, Figure $\mathbf{5 a}, \mathbf{b}, \mathbf{c})$ is also very common, as well as genera Reticulofenestra and Pontosphaera (see Table 1, Figure 5j).

Table 1: Nannofossils extracted from marls at Stops $\mathrm{T} 6\left({ }_{1} \mathrm{~A}, 1 \mathrm{~B}\right)$ and $\mathrm{T}_{7}(2 \mathrm{~B})$ (after Repac, 2017) and their stratigraphic ranges. Redeposited taxa marked by darker colour. Coccolithophores particularly important for biostratigraphic determination of studied marls are Coccolithus miopelagicus and Sphenolithus heteromorphus, marked by bold text in Table 1. Species

Helicosphaera euphratis, if not redeposited, might narrow the stratigraphic span to the very beginning of the zone $\mathrm{NN}_{5}$.

\begin{tabular}{|c|c|c|c|c|c|c|}
\hline \multirow{2}{*}{ Calcareous nannoplankton } & \multirow{2}{*}{ Samples } & \multicolumn{5}{|c|}{ AGE } \\
\hline & & OLDER & NN4 & NN5 & NN6 & YOUNGER \\
\hline Calcidiscus leptoporus & 1B, 2B & & & & & \\
\hline Calcidiscus premacintyrei & $1 \mathrm{~A}, 1 \mathrm{~B}, 2 \mathrm{~B}$ & & & & & \\
\hline Calcidiscus tropicus & $1 \mathrm{~A}, 1 \mathrm{~B}, 2 \mathrm{~B}$ & & & & & \\
\hline Coccolithus miopelagicus & $1 \mathrm{~A}$ & & & & & \\
\hline Coccolithus pelagicus & $1 \mathrm{~A}, 1 \mathrm{~B}, 2 \mathrm{~B}$ & & & & & \\
\hline Helicosphaera carteri & $1 \mathrm{~A}, 1 \mathrm{~B}, 2 \mathrm{~B}$ & & & & & \\
\hline Helicosphaera euphratis & 1B & & & & & \\
\hline Helicosphaera intermedia & $1 \mathrm{~A}, 1 \mathrm{~B}, 2 \mathrm{~B}$ & & & & & \\
\hline Helicosphaera cf. wallichii & 1B & & & & & \\
\hline Pontosphaera discopora & $1 \mathrm{~A}, 1 \mathrm{~B}$ & & & & & \\
\hline Pontosphaera multipora & $1 \mathrm{~A}, 1 \mathrm{~B}, 2 \mathrm{~B}$ & & & & & \\
\hline Pontosphaera plana & $1 \mathrm{~A}, 1 \mathrm{~B}$ & & & & & \\
\hline Reticulofenestra perplexa & $1 \mathrm{~A}, 2 \mathrm{~B}$ & & & & & \\
\hline Reticulofenestra pseudoumbilicus & $1 \mathrm{~A}, 1 \mathrm{~B}, 2 \mathrm{~B}$ & & & & & \\
\hline Rhabdosphaera clavigera & $1 \mathrm{~A}, 1 \mathrm{~B}, 2 \mathrm{~B}$ & & & & & \\
\hline Sphenolithus conicus & $1 \mathrm{~A}$ & & & & & \\
\hline Sphenolithus heteromorphus & 1B & & & & & \\
\hline Sphenolithus moriformis & $1 \mathrm{~A}, 2 \mathrm{~B}$ & & & & & \\
\hline Umbilicosphaera rotula & $1 \mathrm{~A}, 1 \mathrm{~B}, 2 \mathrm{~B}$ & & & & & \\
\hline Transversopontis sp. & $1 \mathrm{~B}$ & & & & & \\
\hline
\end{tabular}



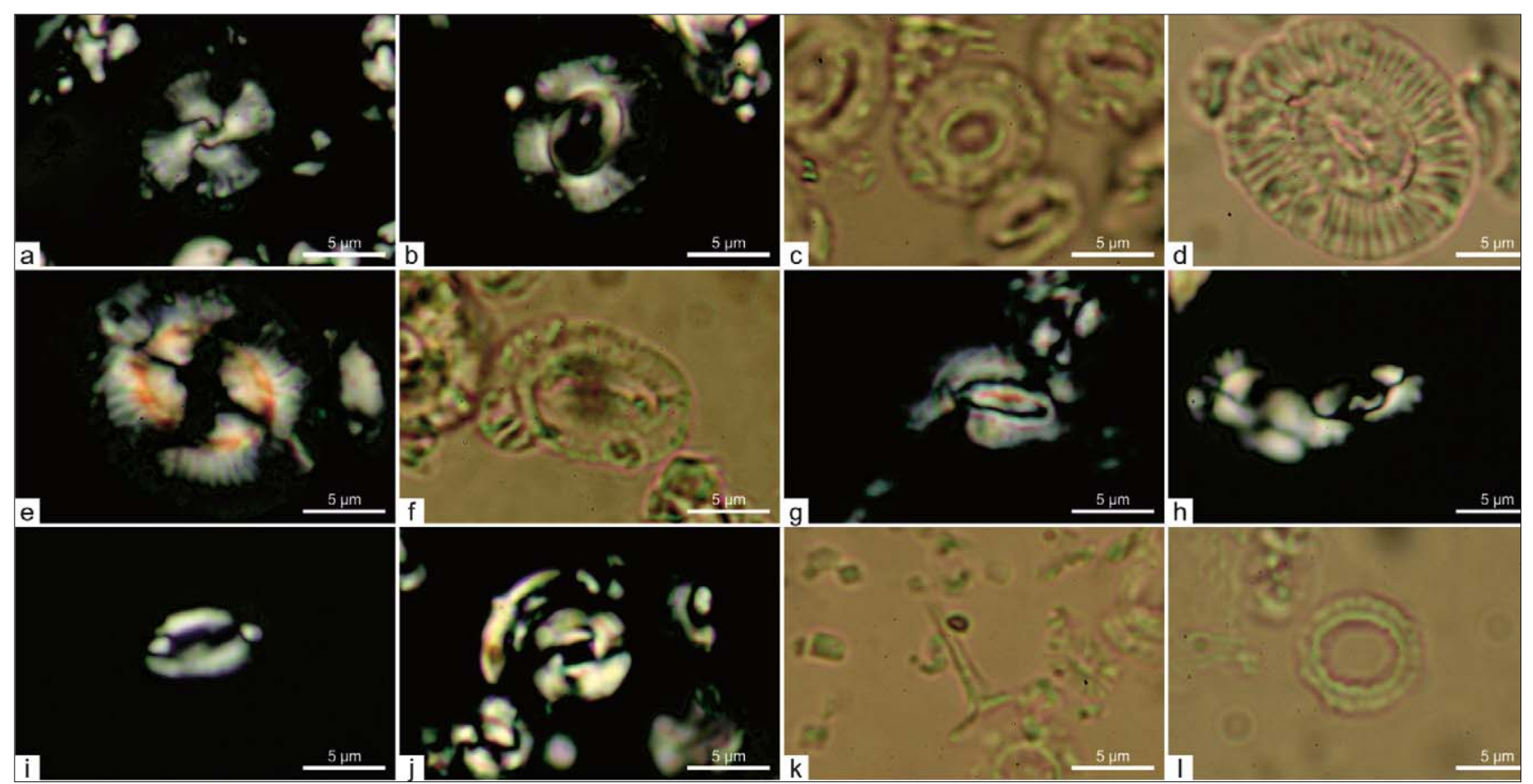

Figure 5: Calcareous nannoplankton from the Badenian marls in the vicinity of Marija Bistrica:

a) Calcidiscus leptoporus (Murray \& Blackman 1898) Loeblich \& Tappan, 1978; b) C. premacintyrei Theodoridis, 1984;

c) C. tropicus (Kamptner, 1956) Varol 1989 sensu Gartner, 1992; d) Coccolithus miopelagicus Bukry, 1971 (PPL);

e) C. miopelagicus Bukry, 1971 (XPL); f) Helicosphaera carteri (Wallich 1877) Kamptner, 1954; g) H. euphratis Haq, 1966;

h) H. intermedia Martini, 1965; i) H. wallichii (Lohmann 1902) Okada \& McIntyre, 1977; j) Reticulofenestra pseudoumbilicus (Gartner, 1967) Gartner, 1969; k) Rhabdosphaera clavigera Murray \& Blackman, 1898; 1) Umbilicosphaera rotula (Kamptner, 1956) Varol, 1982. Sample 1B, Stop T6

\subsection{Calcareous algae}

Calcareous algae are the most common fossils at the studied section (Tripalo, 2017). They are present between Stops T2 and T5 (see Figure 3b) and were determined after Basso et al. (2008), Sarkar (2015), Chelaru and Bucur (2016) and Coletti et al. (2016).

Red coralline algae are the major carbonate producers present as subcircular, crustose or, scarcely, elongate rhodoliths (see Figure 6a-g). Some rhodoliths bear visible conceptacles and could be determined as Hydrolithon lemoinei (Miranda), Hydrolithon sp. and Spongites fructiculosus Kützing (see Figure 6).

Green algae from the family Halimedaceae appear sporadically as bioclasts in the basal part of the section (Stop T2).

\subsection{Foraminifera}

Foraminiferal tests are present in rock samples all along the studied section. Rotaliid benthic foraminifera Cycloclypeus sp., Amphistegina (cf. A. lobifera) (see Figure 7) and Elphidium sp. were determined between Stops T2 and T5. Amphisteginas are more common than other foraminifera, sometimes exhibiting mechanical erosion and corrosion (see Figure 7b). Cross sections of globigerinoid planktic foraminifera appear sporadically in the matrix of basal conglomerates (Stops T1, T5), as well as in clasts of micritic limestones.
Determination of foraminifera from thin sections was based upon Heidari et al. (2013) and Di Martino et al. (2015).

Planktic foraminifera (Orbulina suturalis Brönnimann, Orbulina universa d'Orbigny, Globigerina bulloides d'Orbigny, Globigerinoides sp. div.) dominate in assemblages from marls at Stops T6, T7 and T8, associated with benthic taxa: Heterolepa dutemplei (d'Orbigny), Cibicidoides sp., Lagena striata (d'Orbigny), Glandulina ovula d'Orbigny, Uvigerina macrocarinata Papp \& Turnovsky, Uvigerina sp., Cibicidoides sp. div., Elphidium sp., Lenticulina sp., Nodosaria sp. and Frondicularia sp.

Specimens of planktic (Orbulina suturalis, Globigerina bulloides, Globigerinoides sp.) and benthic foraminifera (Elphidium sp. and Cibicidoides sp.) picked at Stop T7 were used for carbon and oxygen stable isotope analyses in order to determine possible palaeotemperatures and stratification of the sea (Repac, 2017). Palaeotemperature calculations performed by Repac (2017) indicated a diagenetic overprint and gave no significant result for the studied area.

\subsection{Bivalvia}

Badenian sedimentary rocks all around Medvednica Mt. comprise rich and diverse malacofauna which was studied in detail by Kochansky (1944), KochanskyDevidé (1957) and Bošnjak et al. (2017). 

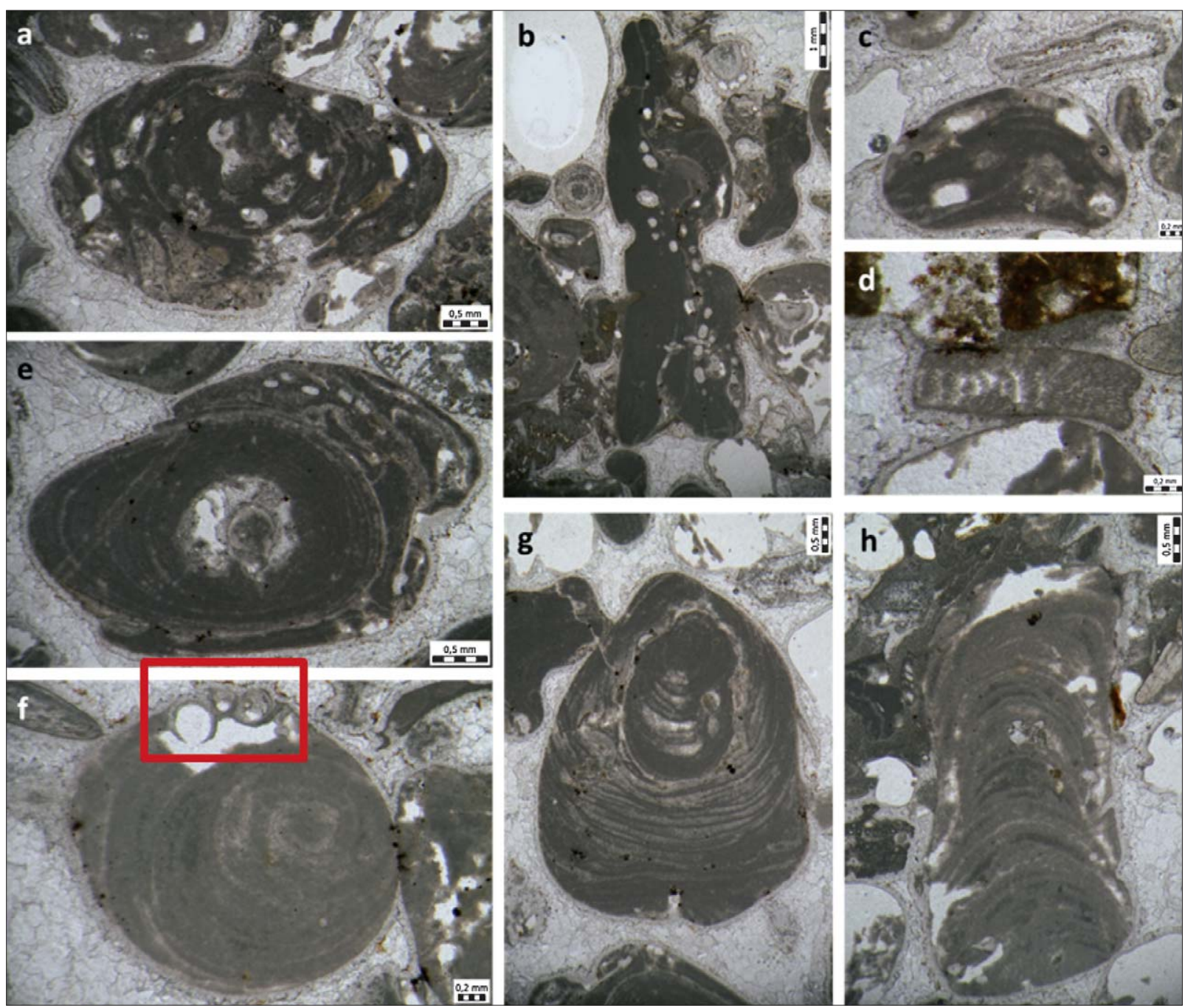

Figure 6: Different shapes of rhodoliths in bioclastic grainstone to rudstone from the studied section: subcircular (a,e,f); crustose (b,c,d) and elongate (g). Taxa with conceptacles are determined as: Hydrolithon sp. (a), Hydrolithon lemoinei (Miranda) (b) and Spongites fructiculosus Kützing (e). Vermetid gastropod overgrowing rhodolith is marked by rectangle (f). Thin sections MB.1; MB.8a,b, Stop T5.
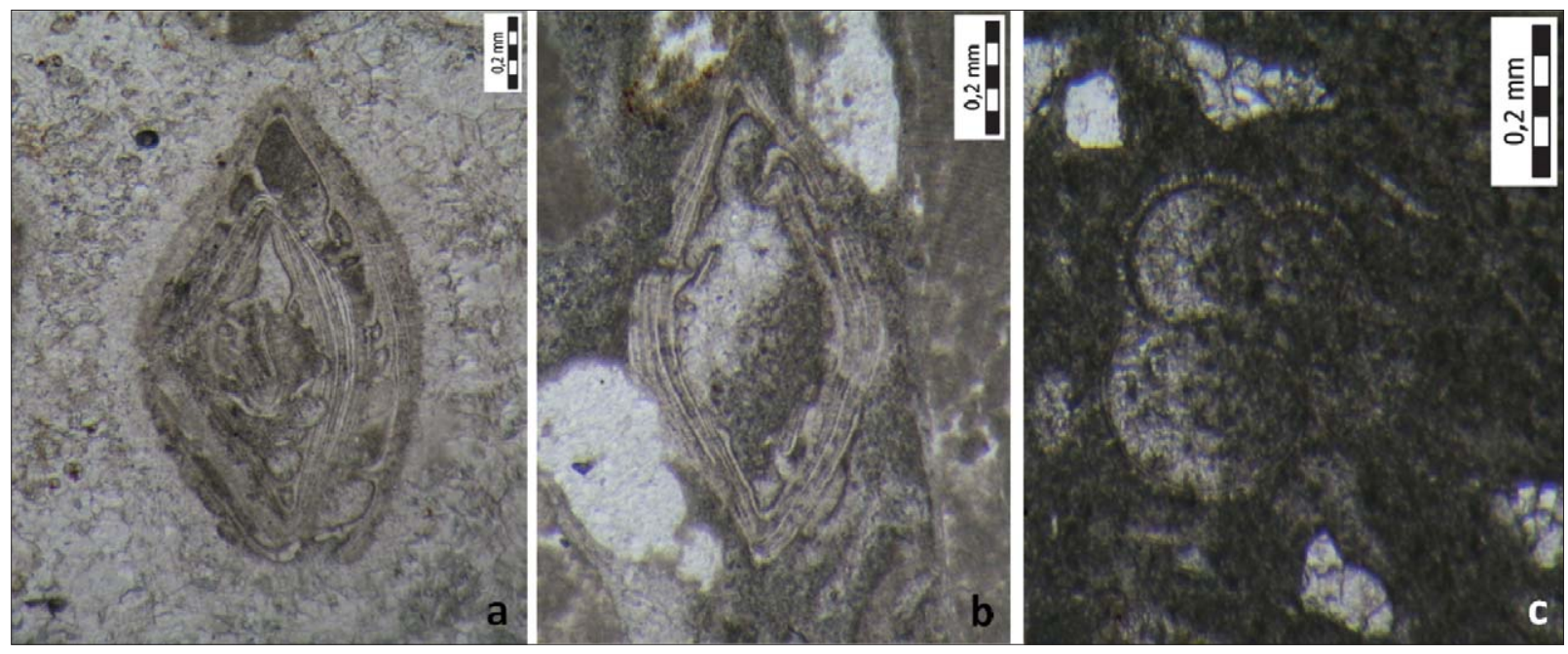

Figure 7: Benthic (a, b) and planktic (c) foraminifera from the Middle Badenian deposits of Marija Bistrica: a, b) Amphistegina (cf. A. lobifera) in different stages of preservation. Its shape is typical for increased water energy and light intensity, according to Beavingtone-Penney and Racey (2004). Corrosion of inner whorls is clearly visible on fig. b). Thin section MB.8b, Stop T5; c) Globigerinoid foraminifera from the matrix of coastal conglomerate. Thin section MB.1, Stop T7. 

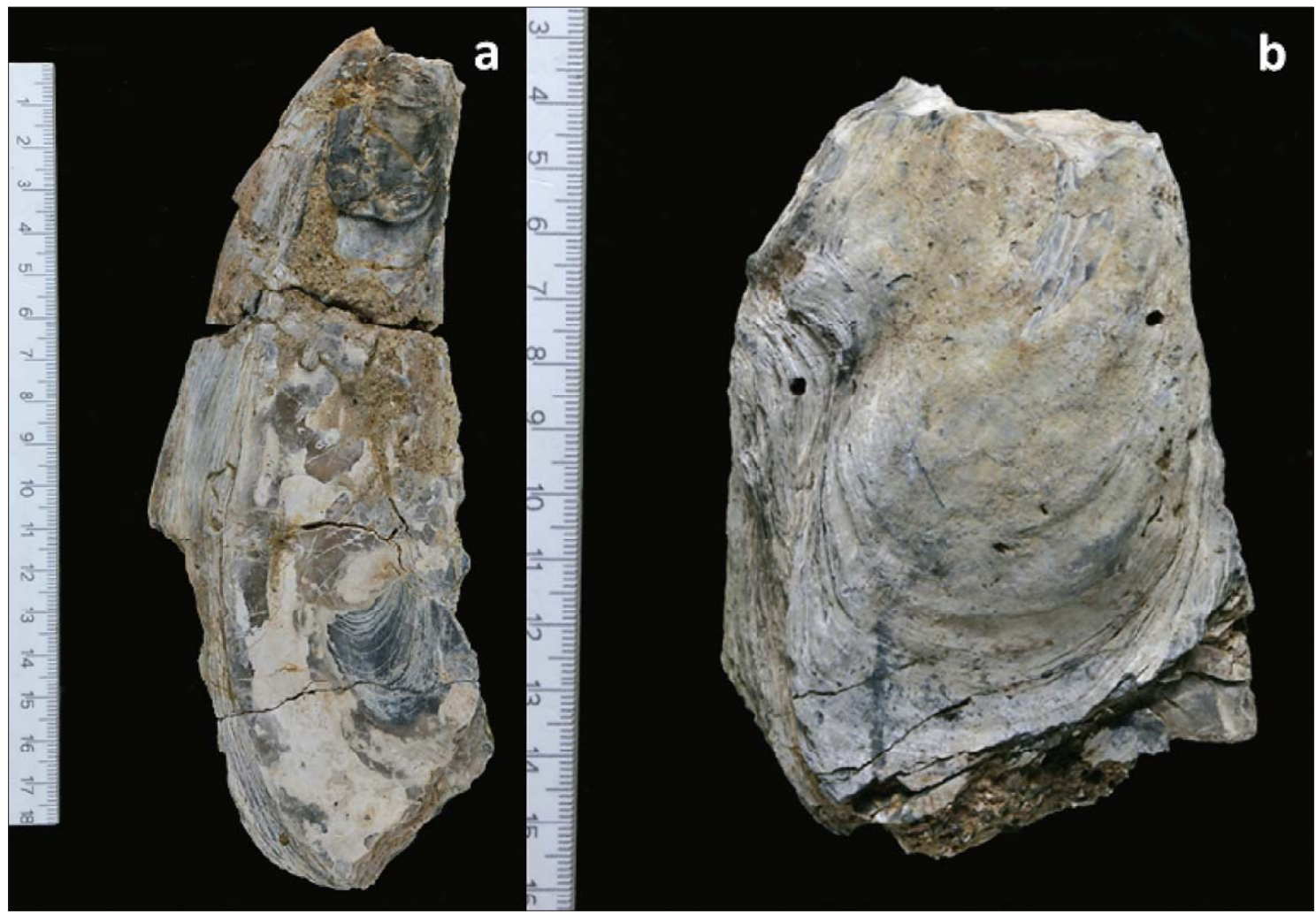

Figure 8: Large oysters from the Stop T5: a) Crassostrea gryphoides (Schlotheim); inventory number CNHM MB4_1 b) Ostrea sp. with scarce clionid borings marked with arrows; inventory number CNHM MB4-A4_1.
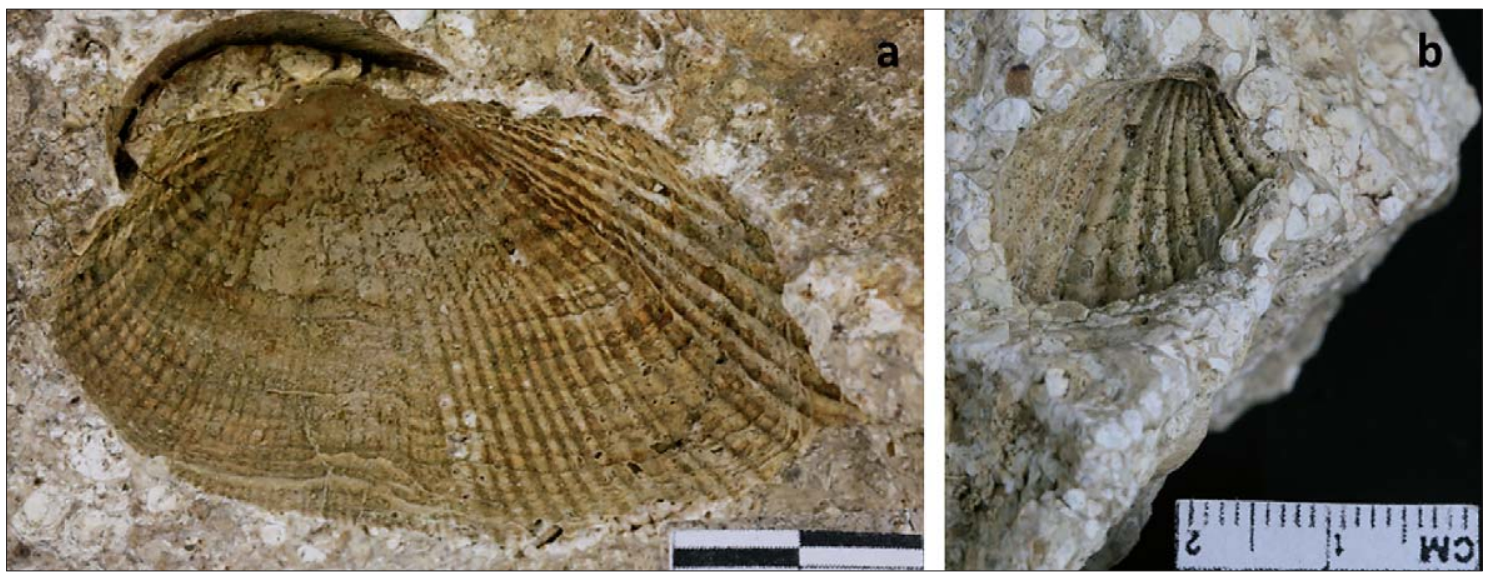

Figure 9: Macrofossils in bioclastic grainstone (Stop T5): a) mold of Arca sp.; inventory number CNHM GR 17; b) mold of Megacardita sp.; inventory number CNHM MB 7.

In the study area, bivalve shells, molds and casts were collected between the Stops T4 and T5. Determination of bivalves was based upon Studencka (1986), El-Hedeny (2005), Hoşgör (2008), De Bortoli and Hladilova (2015) and La Perna et al. (2017).

Large oysters ( 3 whole valves and several fragments) were found laterally, $2 \mathrm{~m}$ northwards from the basal conglomerates at Stop T5. This part of the succession is covered by vegetation. Two oysters were determined as Crassostrea gryphoides (Schlotheim) (see Figure 8a) and one specimen as Ostrea sp. (see Figure 8b). Some valves bear clionid boring traces (see Figure 8b).
Bivalves Arca sp. and Megacardita sp. were determined from bioclastic grainstone at Stop T4 (see Figure 9). Bivalve borings (Gastrochaenolites and Entobia trace fossils) were observed in the basal part of the section.

\subsection{Bryozoa}

Bryozoans are almost as common as coralline algae (Tripalo, 2017). Bifoliate and branched forms predominate in bioclastic grainstone to rudstone facies (see Figure 10), while large irregularly shaped (see Figure 15) and lunulitiform bryozoan colonies occur in floatstones. 


\subsection{Other fossils}

Among other fossils, important findings of pyritized limacinid pteropods in marls (Stops T7, T8) were described by Bošnjak et al. (2017).

Echinoid spines are quite common, mostly of diadematoid and cidaroid origin (see Figure 11a-c). They were determined according to Kroh and Nebelsick (2010) and Di Martino et al. (2015).

Sponge spicules, solitary corals, barnacle particles (see Figure 11d), gastropods (see Figure 11e), scaphopods, brachiopods and ostracods are also present.

\section{Lithotypes}

Polymictic conglomerates, oyster clusters, loose and compact bioclastic deposits and marls occur at the study area (see Figures 12-16).

\subsection{Conglomerates}

The beginning of the Miocene succession is characterized by an up to $2 \mathrm{~m}$ thick layer of polymictic conglomerates. In the basal part of the layer they are clastsupported while in the upper horizon they become matrix-supported. Their packstone to grainstone matrix is composed of coralline algae, bryozoans (including freeliving lunulitiform taxa), pellets, peloids and scarce corals (see Figures 12 and 13).

Occasionally, thin-shelled gastropods and pelagic foraminifera occur within the matrix (see Figure 7c).

The clasts are mostly well rounded, sized up to $4 \mathrm{~cm}$ in diameter. They are composed of diabase, reddishbrown and green sandstone, grey limestone with scarce pelagic foraminifera, black limestone, quartz and chert. Individual carbonate clasts, as well as corals and oyster shells, are often intensely bored by date-shells (Lith-
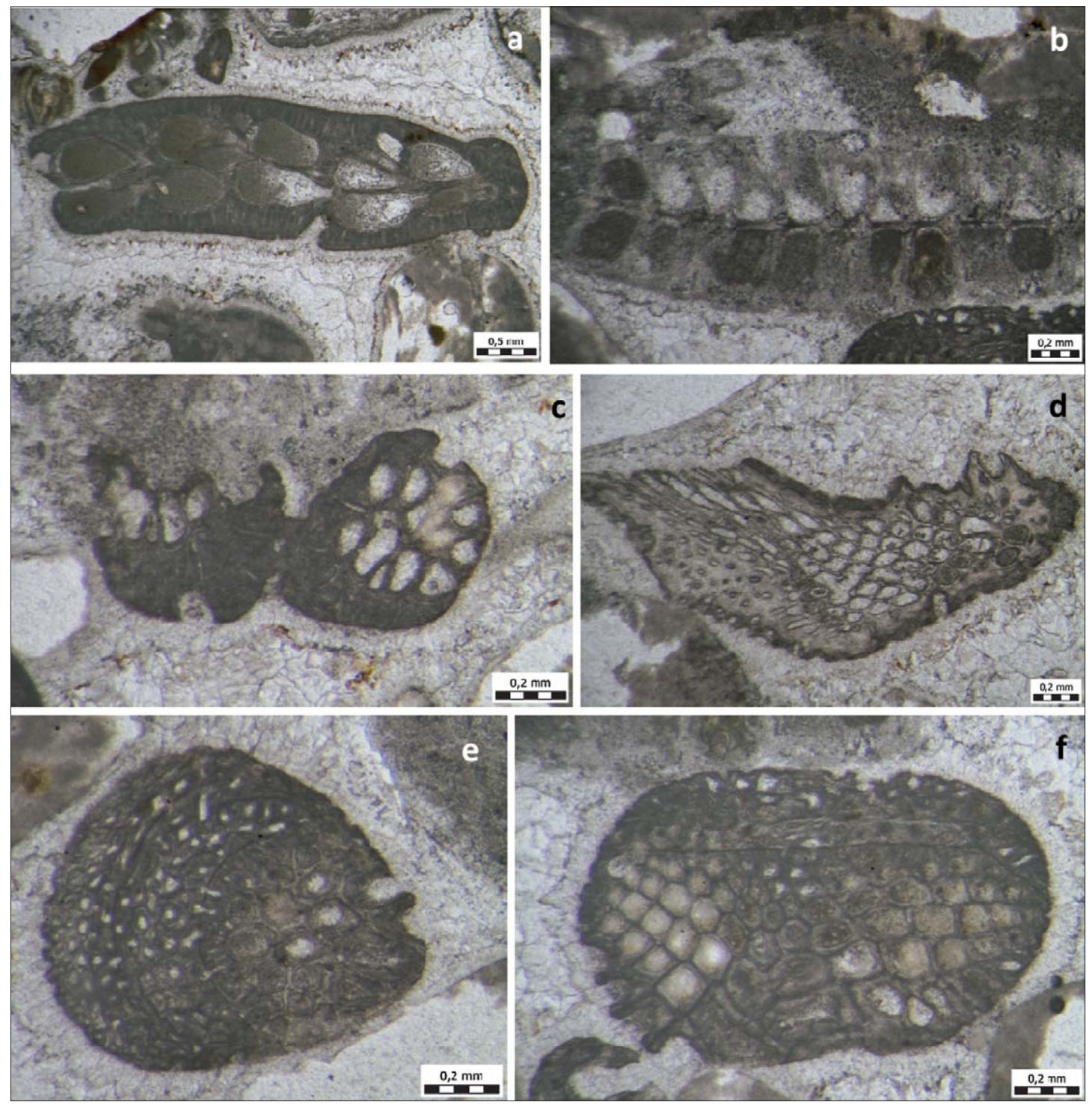

Figure 10: A variety of bryozoans present as bioclasts in bioclastic grainstone to rudstone at Marija Bistrica locality. Bifoliate (a,b) and branched (c-f) forms prevail in this microfacies. Thin sections MB.8a,b, Stop T5. 


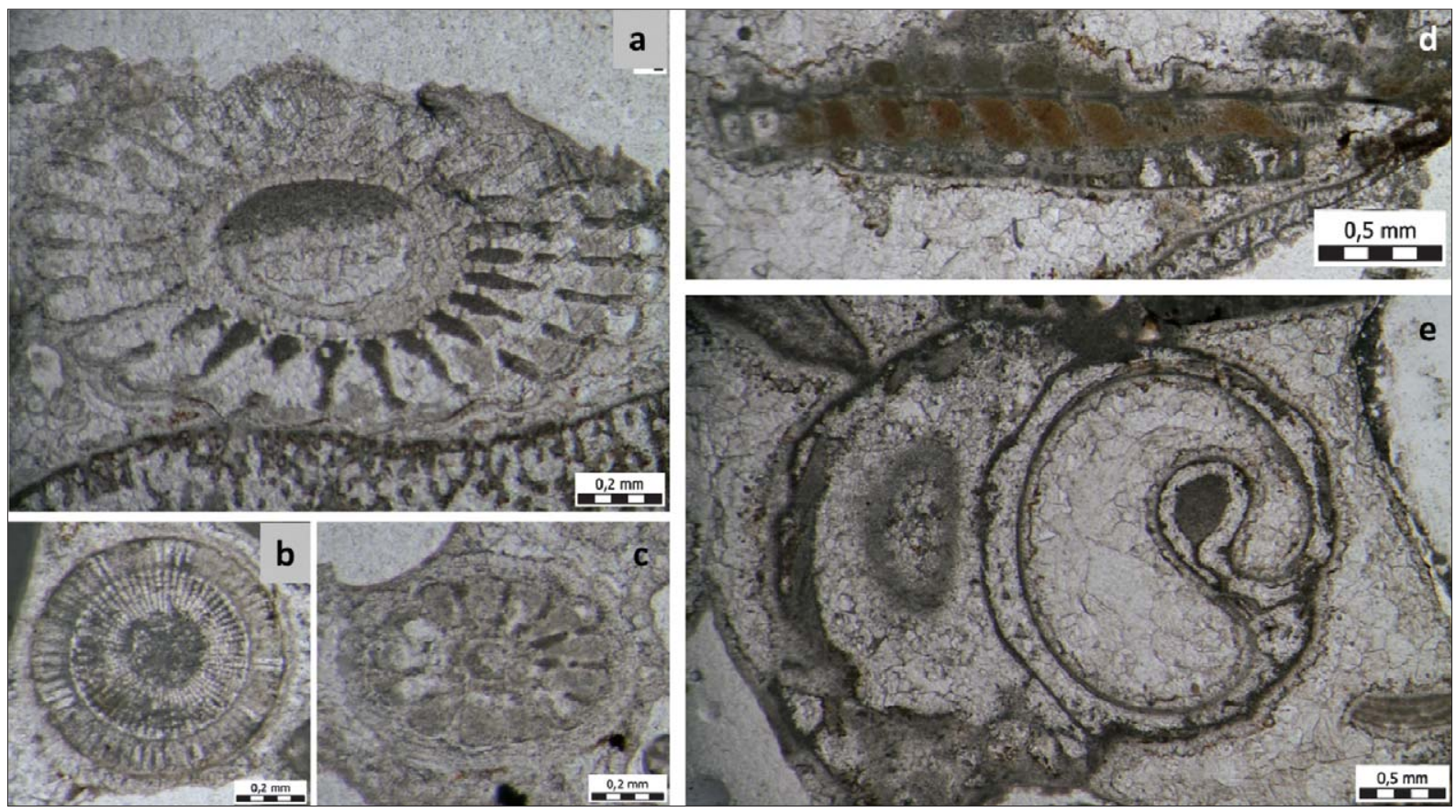

Figure 11: Macrofossil fragments in bioclastic grainstone: a-c) cross sections of different types of echinoid spines; d) barnacle; e) gastropod. Thin sections MB.8a,b, Stop T5.

ophaga) and clionid sponges, or encrusted by red algae and bryozoans (see Figures 12 and 13). Branched bryozoans sometimes occur within the Gastrochaenolites $(=$ date shell) borings (see Figure 13). Similar bioeroded pebbles occur at the base of the Middle Miocene transgressive sequence in Gornje Orešje quarry, ca $10 \mathrm{~km}$ to the East (Brlek et al., 2016; Moro et al., 2016).

Pebbles originate from the weathered Palaeozoic and Mesozoic basement which prevails in the study area (Šikić et al., 1978, 1979; Tomljenović, 2002).

\subsection{Oyster clusters}

Large oyster shells found near Stop T5 are sometimes preserved in clusters. Clionid borings are found on one shell (see Figure 8b).

\subsection{Compact bryozoan-algal bioclastic grainstone to rudstone facies}

The most compact, reef-like deposits are exposed at Stop T5. At the first sight they look like a typical "Lithothamnion Limestone". They comprise a variety of biota, including halimedas and corallines, mollusks, bryozoans and echinoderms. Microfacies analyses show a grainstone to rudstone microstructure (see Figure 14).

Skeletal grains, particularly Bryopsidales (Halimeda) and bryozoan fragments, are in most cases fragmented and coated with cortoid envelopes. Bioclasts are cemented with coarse-grained sparry calcite. Spheroidal rhodoliths exhibit less pronounced traces of mechanical erosion, while encrusting and branching forms are subordinate and present as crushed fragments.
Among macrofossil bioclasts, calcite oyster shell fragments remain undissolved (see Figure 8), while aragonite-shelled bivalves Arca sp. and Megacardita sp. (see Figure 9) are present only as molds.

\subsection{Compact bryozoan-algal-coral floatstone}

Deposits with bioclasts larger than $2 \mathrm{~mm}$ clearly differ from the previous type of facies. They appear sporadically as a lateral facies of the previously described grainstone.

Cyclostome bryozoan colonies are larger and irregularly-shaped in this facies, whereas solitary corals (Flabellum? sp.) are scattered within the matrix. Bioclasts are sometimes bioeroded by date mussels or clionid sponges (see Figure 15). Small benthic and planktic foraminifera and minute thin-shelled gastropods are preserved in the matrix, as well as within the borings.

\subsection{Loosely packed bioclastic deposits}

Rhodolith beds, in older literature described as "Lithothamnion (previously: Lithothamnium) Sandstones" represent the most loosely packed bioclastic deposits at the studied outcrop. They occur in the southern part of the section and seem to laterally replace the grainstone lithofacies, or partly lie over it. They are heavily weathered and it is hard to prepare a thin section from this facies.

Rhodoliths in this lithofacies are in most cases smaller than $2 \mathrm{~mm}$; although they can sometimes exceed this dimension, forming a packstone to floatstone sedimentary rock (see Figure 16). Dominant corallines are 


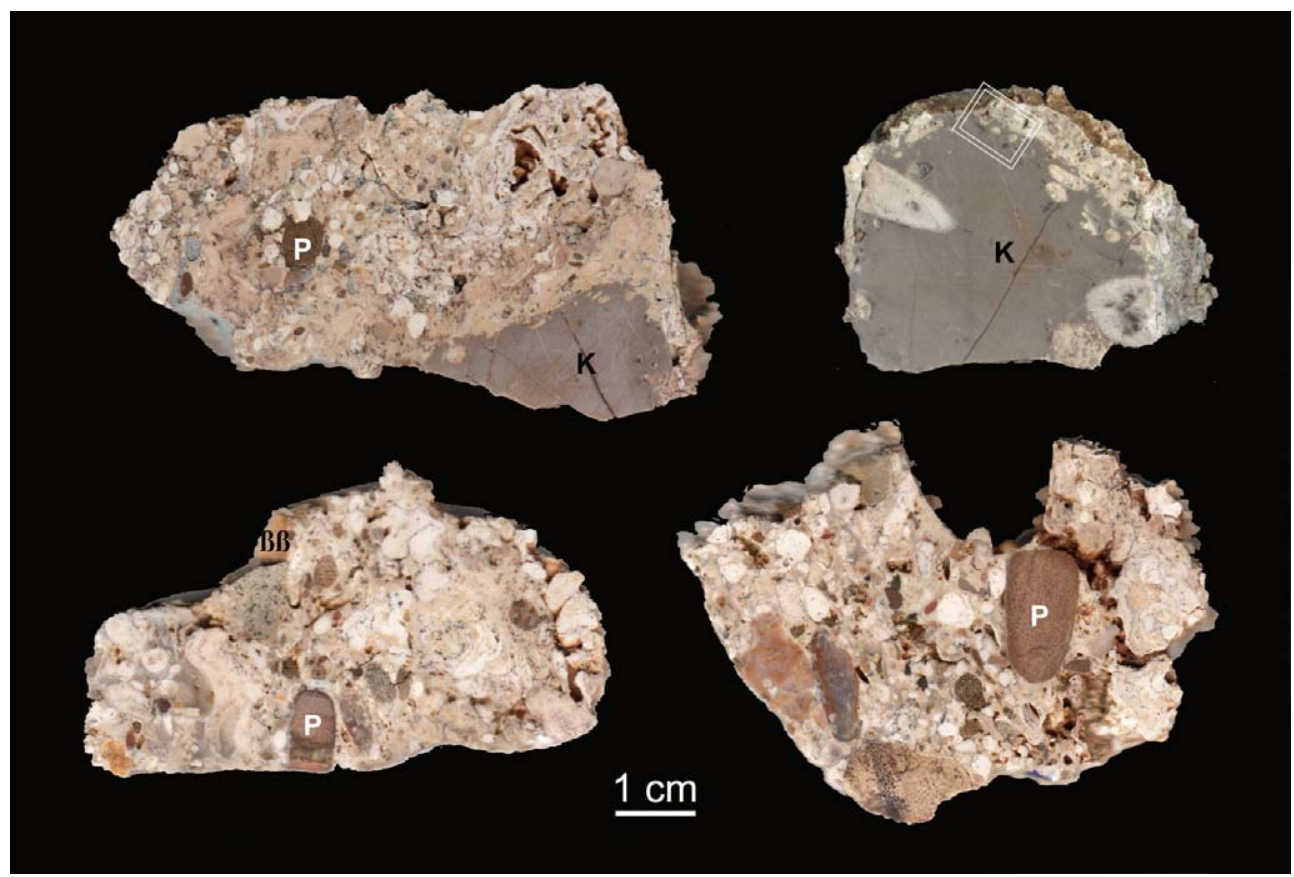

Figure 12: Polished sections of basal Miocene conglomerates from the studied locality, Stop $\mathrm{T}_{5}$. Reddish-brown elongate pebbles (P) represent sandstones (? Permian or Lower Triassic) from the bedrocks (see Figures 2 and 4). Green-coloured, less rounded fragments are diabases $(\beta \beta)$, also present in the study area (see Figures 2 and 4 ). Dark grey, larger pebbles of pelagic limestones with traces of bioerosion, Gastrochaenolites-Entobia ichno-assemblage (K) are probably of Cretaceous age. A detail marked by rectangle is shown in Figure 13.

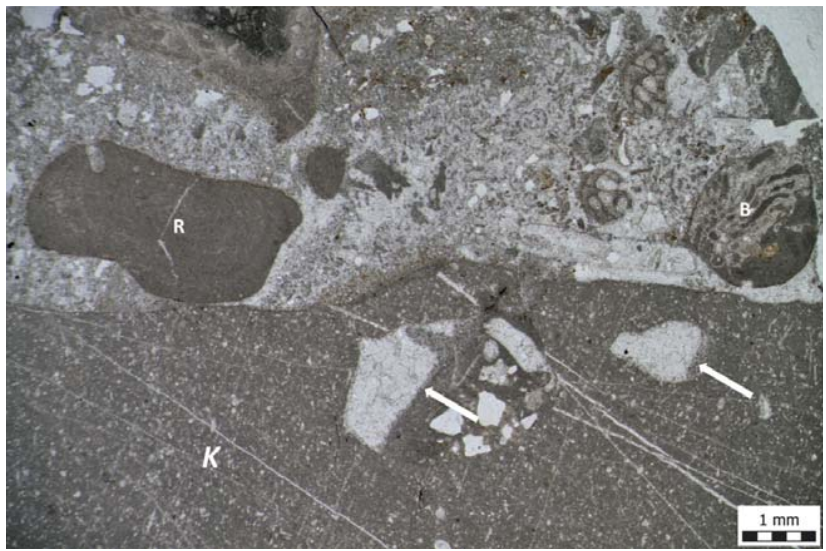

Figure 13: Photomicrograph of conglomerates with a large angular fragment of pelagic limestone in the lower part possibly of the Cretaceous age $(K)$, with geopetally filled Gastrochaenolites boring traces (original upward position marked by arrows), rhodoliths (R) and bryozoans, some of which grew inside the date mussel burrow (B). Position of thin section is marked by white rectangle in Figure 12. Thin section MB1, Stop $\mathrm{T}_{5}$.

Lithothamnion crispatum Hauck and Spongites sp. (Tripalo, 2017). Other fossils are less common, but bryozoans, echinoderms and small benthic foraminifera were also recorded in this facies.

\subsection{Marls}

Grey to yellowish-grey marls occur in the northern part of the succession and represent the youngest litho-

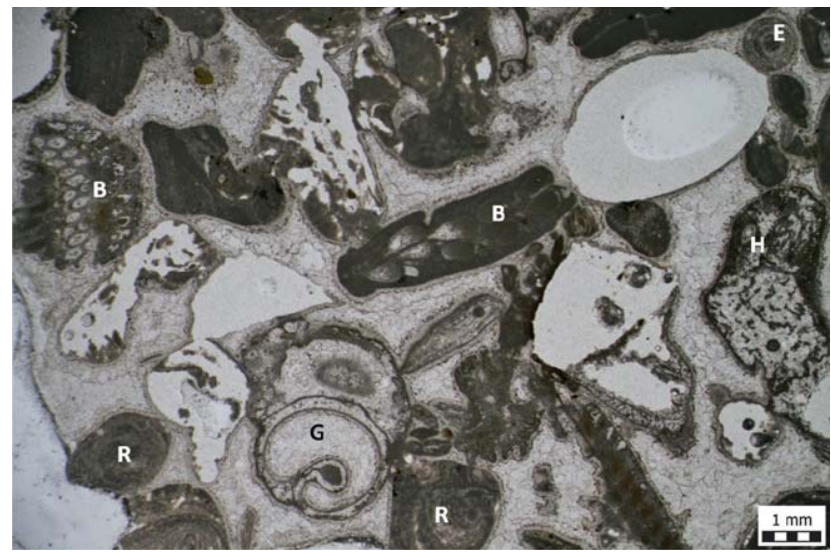

Figure 14: Algal-bryozoan grainstone with rhodoliths $(R)$, Halimeda $(\mathrm{H})$, bryozoans $(\mathrm{B})$, gastropods $(\mathrm{G})$ and echinoderms (E). Slide MB.8a, Stop T5.

stratigraphic unit at the studied section (see Figure 4). Their contact with rhodolith beds and/or basal conglomerates is not visible due to the dense vegetation.

A rich coccolithophore assemblage was found in the finest sediment fraction (see Table 1). Fractions larger than $0.063 \mathrm{~mm}$ comprise $85 \%$ or more bioclasts, with up to $15 \%$ lithoclasts. The most common fossils are planktic foraminifera, with up to $80 \%$ of all fossils, accompanied with small benthic genera. The following foraminiferal taxa were determined: Orbulina suturalis Brönnimann, Orbulina universa d'Orbigny, Globigerina bulloides d'Orbigny, Globigerinoides sp. div., Heterolepa dutemplei (d'Orbigny), Cibicidoides sp., Lagena 


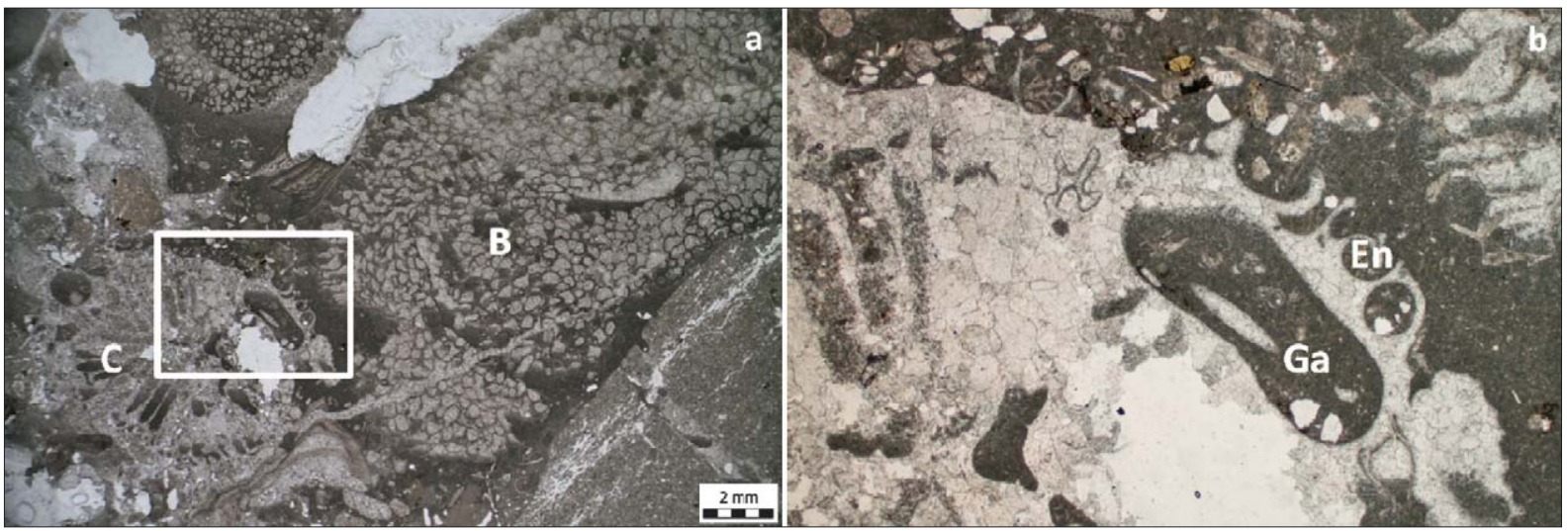

Figure 15: a) Bioclastic bryozoan floatstone with scattered solitary corals Flabellum? sp. (C) and large bryozoan colonies (B). b) Enlarged detail: recrystallized corallite with traces of bioerosion, Gastrochaenolites (Ga) and Entobia (En). Stop T7, Slide MB.2.

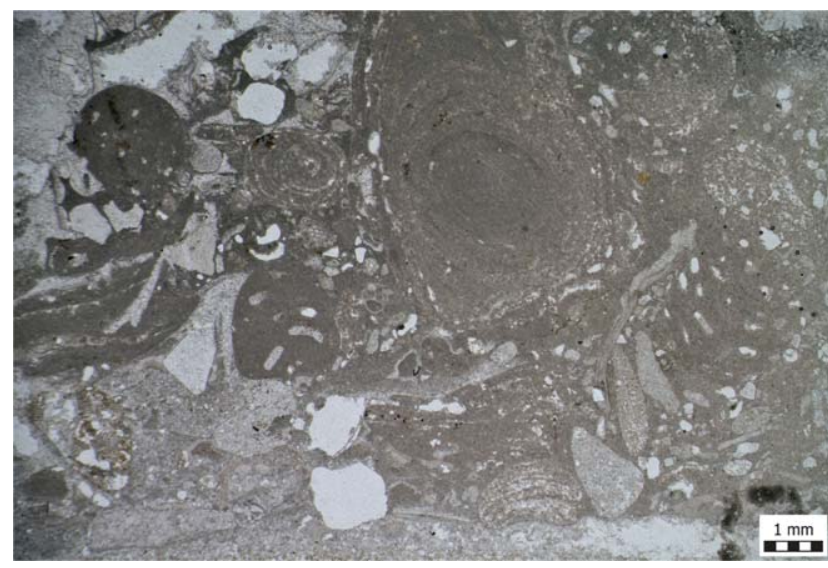

Figure 16: Rhodolith packstone to floatstone with Lithothamnion crispatum Hauck and Spongites sp. Some rhodoliths show traces of bioerosion. Thin section MB.1, Stop 7.

striata (d'Orbigny), Glandulina ovula d'Orbigny, Uvigerina macrocarinata Papp \& Turnovsky, Uvigerina sp., Elphidium sp., Lenticulina sp., Nodosaria sp. and Frondicularia sp. The amount of orbulinid planktic foraminifera slightly decreases in younger horizons ( $\mathbf{R e}-$ pac, 2017).

Accompanying fauna comprises limacinid pteropods, bryozoans, scaphopods, ostracods and brachiopods. Sponge spicules were found sporadically (Bošnjak et al., 2017).

\section{Discussion}

\subsection{Stratigraphic age}

Stratigraphic studies of the Miocene marine deposits are mainly based upon calcareous nannofossils and foraminifera (e.g. Grill, 1941; Berggren et al., 1995; Cicha et al., 1998; Hohenegger et al., 2007, 2009; Anthonissen and Ogg, 2012). Combined with other (lithostratigraphic, magnetostratigraphic, chemostratigraphic) data, generalized chronostratigraphic papers offer a good framework for Miocene deposits studies (Berggren et al., 1995; Hardenbol et al., 1998; Gradstein et al., 2004).

Several authors discuss the stratigraphic range of the Middle Miocene transgressive-regressive deposits in Central Paratethys, based upon their palaeontological and/or sedimentological features (Rögl et al., 2008; Hohenegger et al., 2009, 2014; Janson et al., 2010; Zágoršek et al., 2010; Martinuš et al., 2013; Sant et al., 2015, 2017; Pezelj et al., 2016) (Figures 17 and 18).

Badenian transgressive-regressive sequences were recorded at different localities surrounding Medvednica Mt. The Middle Badenian (sensu Hohenegger et al., 2014; Figure 17) transgressive-regressive sequence TB 2.4 has been presumed for the areas of Čučerje and Vejalnica (Ć́orić et al., 2009; Bošnjak et al., 2017; Marković, 2017; Pavelić and Kovačić, 2018). Approximately $80 \mathrm{~km}$ SSE from Medvednica Mt., at the Zrin locality, Martinuš at al. (2013) described fossiliferous, dominantly carbonate succession, stratigraphically attributed to the Nannozones NN4 to NN5. Similarities with the Middle Miocene deposits near Marija Bistrica can be observed particularly in the uppermost part of the Zrin section. A Middle or Upper Badenian age of the transgressive Miocene sequence (sequences TB 2.4 or 2.5) in Gornje Orešje was proposed by Brlek et al. (2016). The Late Badenian 2.5 sequence is generally considered to be widespread around Medvednica Mt. (Pavelić 2001, 2005; Vrsaljko et al., 2006; Pezelj et al., 2007, 2016; Sremac et al., 2016; Tripalo et al., 2016; Bošnjak, 2017; Pavelić and Kovačić, 2018).

A stratigraphic range of transgressive succession in the study area was discussed by Avanić et al. (2003), who, according to benthic and planktic foraminifera and nannofossils suggested a Middle, or more likely, Late Badenian age (NN6 Nannozone). Nannoplankton analyses from pteropod marls near Marija Bistrica (Bošnjak et al., 2017) indicated a stratigraphic span from the NN5 to NN6 Nannozone (Middle to Late Badenian).

Calcareous nannoplankton (see Table 1), planktic foraminifera and planktic gastropods were determined 


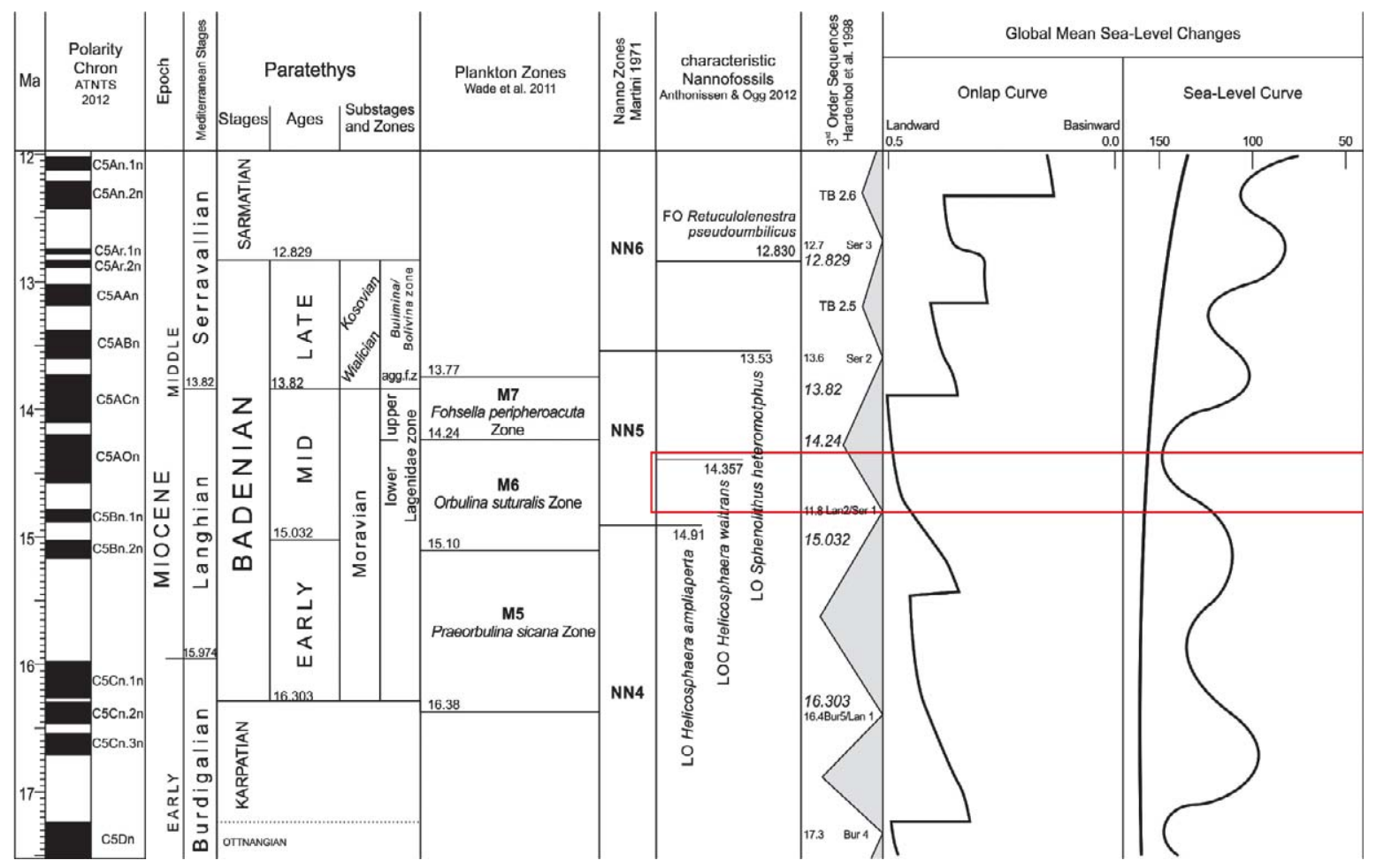

Figure 17: Correlation of global and regional stratigraphy, polarity chrons, biozones and transgressive-regressive sequences in the Miocene of the Paratethys (after Hohenegger et al., 2014). Global sea-level change and coastal onlap curve after Haq and Al Qahtani (2005). Rectangle marks the most probable age of the transgressive succession in the surrounding of Marija Bistrica.

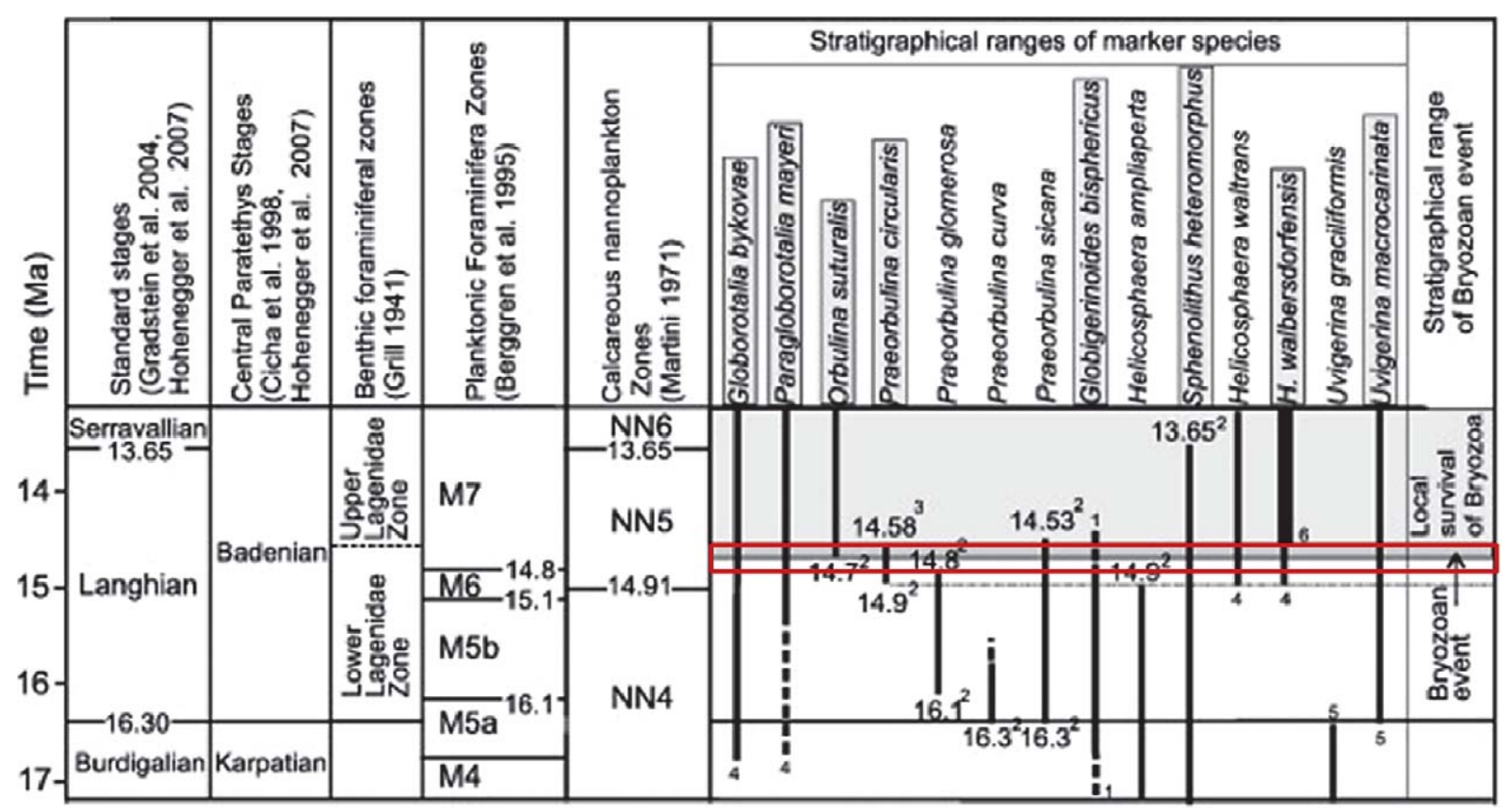

Figure 18: Correlation of global and regional stratigraphy, foraminiferal and calcareous nannoplankton zones and timing of Bryozoan event in the Miocene of the Paratethys (Holcová and Zágoršek, 20o8), with most probable age of the transgressive sequence in the area of Marija Bistrica marked by red rectangle. 
from marls at Stop 7 of the studied section. Calcareous nannoplankton assemblage comprises several taxa redeposited from older, probably Oligocene deposits (e.g. Pontosphaera plana, Sphenolitus conicus, Transversopontis sp., see Table 1). The species Sphenolithus heteromorphus points to the NN4-NN5 Nannozone span, while Coccolithus miopelagicus is present since the NN5 Nannozone (see Table 1), which narrows the stratigraphic span of the studied section to the NN5 Nannozone, despite the lack of the NN5 Zone proxy, Helicosphaera waltrans. The species Helicosphaera eufratis according to the Nannotax base last appears within the NN4 Zone. It might be redeposited from older deposits, or might narrow the proposed time-span of the studied marls to the very beginning of the NN5 Zone.

The pteropod species Limacina valvatina, found in marl samples from Stop 7 inhabited wide areas of the Paratethys during the Middle Miocene (Bošnjak et al., 2017 and references therein).

At the same time, in marl samples from Stop 7 abundant specimens of large planktic foraminifera Orbulina suturalis and $O$. universa appear together with globigerinids. The assemblage can be correlated with the Orbulina suturalis Zone (M6 Plankton Zone, sensu Wade et al., 2011), or eventually with its transition into the Fohsella peripheroacuta Zone (M7 Zone). Both of these zones can be correlated with the NN5 Nannozone (sensu Martini, 1971) (see Figures 17, 18).

The last argument for the suggested Middle Badenian age of the studied deposits is the abundance and diversity of bryozoans, typical for the Paratethys "Bryozoan event" which ended almost immediately after the beginning of the M7 Plankton Zone. Since then, only local findings of bryozoans were recorded (Holcová and Zágoršek, 2008) (see Figure 18).

\subsection{Palaeoenvironments}

Previously described lithotypes indicate the deposition on a slightly inclined ramp subjected to drowning processes. The following palaeoenvironments can be recognized from the fossil assemblages (see Figure 19):

\section{Beach (Lithotype 1)}

Basal deposits at the studied section are represented by clast to matrix-supported polymictic conglomerates exposed under the bioclastic Middle Miocene deposits. They are visible between Stops T2 and T5 over a length of at least $25 \mathrm{~m}$ forming a continuous layer. Pebbles are rounded bedrock fragments, commonly sized up to $1 \mathrm{~cm}$ in diameter, but larger fragments are also present (see Figure 12). They are supported with bioclastic matrix derived from skeletal particles of marine biota. A lack of terrigenous debris in the matrix may indicate a less pronounced topography in the hinterland, low precipitation and low weathering rate common at the end of the Middle Miocene (Böhme et al., 2008, 2011; Bruch et al., 2011). Lithoclasts composed of the surrounding older
pre-Cenozoic rocks (diabase, reddish-brown and green sandstone, grey pelagic limestone) are diverse and well rounded, which indicates that they could have been previously eroded from the hinterland, abraded and transported by river(s) as described by Avanić et al. (2003), and later deposited on a beach and shallow sea floor.

\section{Oyster banks (Lithotype 2)}

The existence of a possible oyster-bank in the study area is presumed on the basis of secondarily found well preserved oyster macrofossils (Crassostrea gryphoides, Ostrea sp.).

Local oyster banks (clustered shells) were present in the intertidal zone all along the Middle Miocene Paratethys shores (De Bortoli and Hladilova, 2015 and references therein). Such banks in modern environments are often influenced by input of nutrient rich fresh-water near the river mouths (Gain et al., 2017 and references therein). The existence of the Middle Miocene alluvial clastic deposits in the study area recorded by Avanić et al. (2003) might support this interpretation.

\section{Lagoons and embayments (Lithotype 3)}

Lagoons and embayments were inhabited by green macroalga Halimeda, branched and rhodolith-forming corallines and bryozoans. They were partly isolated from the open sea by small rhodalgal-bryozoan bioconstructions. Tropical storm waves brought reef debris and even some planktic biota into the lagoons and embayments. Such deposits exhibit grainstone to rudstone microstructure with cortoid films and sparry cement, (see Figure 14).

Several authors mention the flourishment of Halime$d a$ macroalgae during the Late Miocene (e.g. Mankiewicz, 1988; Braga et al., 1996), but Bucur et al. (2011) describe them from the Middle Miocene deposits of the Transylvanian Basin in Romania, where they also coexisted with red algae and benthic foraminifera.

The species Hydrolithon lemoinei (Miranda) and Spongites fructiculosus Kützing are the most common red algae in this facies (see Figure 6). In studied samples, minute rhodoliths are found together with small bryozoan colonies (see Figure 10). As bryozoans and red algae are competitors, their relative abundance is a key to understand trophic levels. While algae prefer oligotrophic conditions, bryozoans flourish in mesotrophic to eutrophic environments (Zágoršek, 2015 and references therein). The dominance of algae over smallsized bryozoan colonies in this facies points to a low trophic level.

Amphisteginids (benthic foraminifera) present in this facies sometimes bear traces of test corrosion. Their lenticular forms additionally indicate increased water energy and light intensity (Beavingtone-Penney and Racey, 2004) (see Figure 7).

Bivalves, echinoid spines, barnacle particles and spherical gastropods are also common in such environment (see Figures 9 and 11). Aragonite bivalve shells 


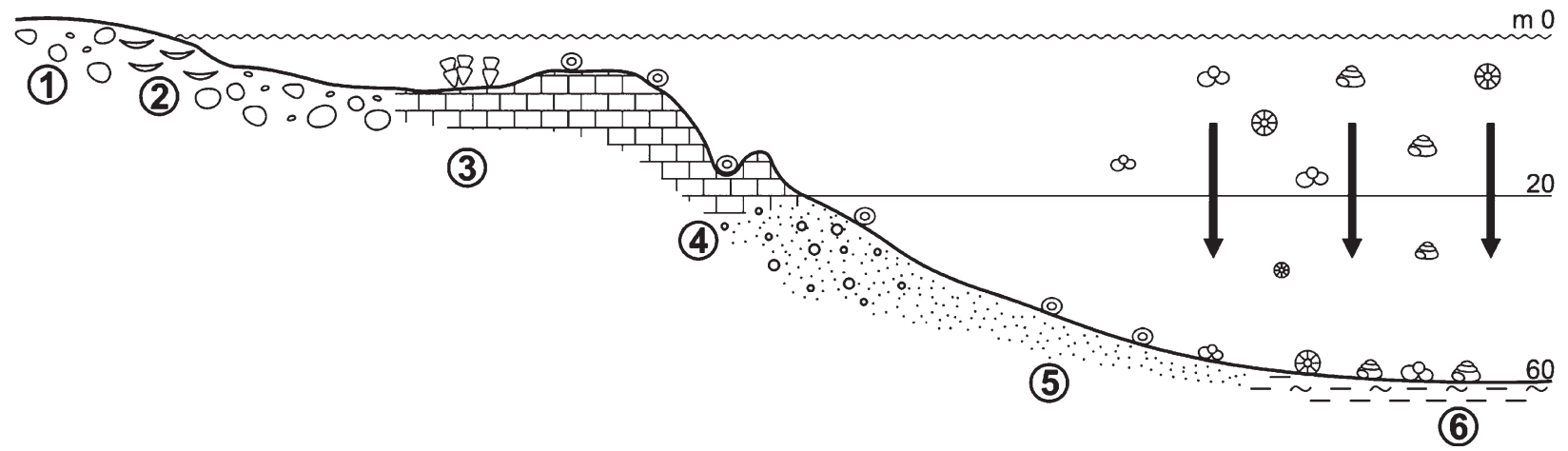

Figure 19: Reconstruction of palaeoenvironments during the Middle Miocene in the area of today's Marija Bistrica (assemblages reconstructed after Wilson and Wecsei, 2005; sedimentary features after Braga et al., 2009). Numbers indicate the following environments: 1 . Beach and proximal shelf; 2. Oyster banks; 3. Lagoons and embayments; 4. Patch reefs and surrounding bioclastic deposits; 5. Maërl; 6. Distal slope. Dimensions not to scale.

(Arca, Megacardita) are dissolved, while calcite oysters were mechanically destructed and present as fragments (see Figures 8 and 9). Dissolution of aragonite shells indicates the influence of fresh water in the vadose zone.

Patch reefs and surrounding bioclastic deposits (Lithotype 4)

Reefs and mounds were formed in many places along the shelves of the Central Paratethys during the Middle Miocene. In most cases they are not preserved in situ, but as fragments in bioclastic talus deposits (e.g. Braga et al., 2009 and references therein). Dominant bioconstructors, including the red algae and bryozoans, were described by various authors (e.g. Wilson and Wecsei, 2005; Martinuš et al., 2013; Sremac et al., 2016 and references therein). The Middle Miocene (Badenian) "Bryozoan event", a bryozoan bloom in the Paratethys, was described in several papers (e.g. Holcova and Zágoršek, 2008; Zágoršek et al., 2008 a,b, 2010; Zágoršek, 2015 and references therein).

Bioclastic slope deposits are characterized by a floatstone texture (see Figure 15). The presence of solitary corals, together with the dominance of bryozoans (forming large colonies) over calcareous algae, point to a somewhat deeper and cooler shelf environment and at least mesotrophic, or even eutrophic conditions. Corals of the genus Flabellum (see Figure 15) do not have zooxantellid symbionts and can live in a wide range of water depths, from 36 up to $2260 \mathrm{~m}$ (Buhl-Mortensen et al., 2007). Date shell and clionid sponge borings visible on some coral specimens (see Figure 15) appear mainly in the area battered by waves, but have also been found at the depth of $200 \mathrm{~m}$ (Eccen and Çinar, 2015 and references therein). It is also possible that coral and bryozoan fossils are bioclasts transported from other surrounding habitats with previously described environmental conditions.

\section{Maërl (Lithotype 5)}

Rhodolith or maërl beds, dominated by free living coralline algae, are common in ancient and modern subtidal environments all over the world, as studied by numerous authors (e.g. Foster et al., 2013; Horta et al., 2016 and references therein). They are formed by aggregations of nongeniculate coralline algae, appear in a high variety of forms and provide suitable habitats for numerous other marine organisms. Their growth is controlled by a combination of light intensity and water motion which prevent their burial and anoxia. Rhodolith beds occur from tropical to polar waters, from the lower intertidal zone down to depths $150 \mathrm{~m}$ (Foster et al., 2013). Fossil rhodolith beds are, in most cases, preserved as grainstones.

The rhodolith assemblage from this facies, collected at Stop 7, is accompanied with diverse shelf biota (bryozoans, foraminifera, bivalves, gastropods, tube worms, echinoids). The most common rhodolith producers are Lithothamnion crispatum, today mostly present at depths of 20-25 m, and Spongites sp. which in most cases inhabits subtidal environments up to $75 \mathrm{~m}$ depth.

Lithological features and presence of Lithothamnion crispatum indicate a shallow subtidal environment below the fair weather wave base for this type of facies.

\section{Distal slope (Lithotype 6)}

Marls with dominantly pelagic biota (planktic foraminifera, coccolithophores and limacinid pteropods) point to a distal slope environment (Wilson and Wecsei, 2005; Braga et al., 2009). The depths might extend up to several hundred meters. Aragonite tests are lacking, while common presence of framboidal pyrite within gastropod tests and in the muddy matrix indicates hypoxic to anoxic conditions at the sea floor (Jansen, 1984; Bošnjak et al., 2017 and references therein).

Orbulinid planktic foraminifera decrease in number in younger marl horizons, while globigerinoid tests become more abundant. Some authors connect such turnover in pelagic communities with a cooling event at the end of the Langhian and the beginning of the Serravalian stage (Zágoršek et al., 2010).

Due to the diagenetic overprint tests of studied foraminifera were not suitable for isotopic analyses and palaeotemperature interpretations (Repac, 2017). 
The total thickness of the studied section is rather small (ca. 15 m; see Figure 4), but it nevertheless comprises diverse lithofacies units, indicating a carbonate ramp depositional setting. Almost all bioconstructions were destroyed by wave action and can be recognized only from fragments in bioclastic deposits. Planktic foraminifera present in the matrix of basal conglomerates indicate a connection with the pelagic realm. Direct contact between marls and underlying bioclastic deposits is not visible, but it seems, as presented in Figure 4, that they overlie shallow-marine deposits after only a few meters, indicating a rapid sea-level rise and abrupt changes in sedimentary conditions.

\section{Conclusions}

The Middle Miocene sedimentary succession in the area of Marija Bistrica comprises deposits from different depositional environments.

Polymictic, clast to matrix-supported conglomerates transgressively overlie Palaeozoic and Mesozoic basement rocks. They are moderately sorted, but pebbles are well rounded and supported with bioclastic debris derived from a shallow marine environment. Pebbles, reflecting diverse bedrock lithologies, could have been, at least partly, brought to the seashore by a nearby river.

Oyster banks were formed sporadically in intertidal zone, possibly near the river mouth.

Rhodolith assemblages found in loosely packed bioclastic deposits (packstones to floatstones) are typical for a subtidal zone with depths between 20 and $30 \mathrm{~m}$.

Lagoonal environments were present locally, characterized by green Bryopsidales macroalgae, small rhodoliths, fragile branched bryozoans and gastropods. Oligotrophic conditions lead to the domination of algae over the bryozoans. Evaporation in isolated lagoons enabled the precipitation of sparry calcite and cementation of skeletal grains and formation of cortoid films around bioclasts, thus producing a grainstone to rudstone fabric.

Coralgal-bryozoan bioconstructions represented local barriers between the lagoons and open-sea environment. They were not preserved in situ, but in the form of bioclasts transported to the talus slope, forming floatstone to rudstone deposits. They comprise large bryozoan colonies and bioeroded solitary corals, indicating a higher trophic level in a somewhat deeper environment, possibly between 30 and $75 \mathrm{~m}$.

Marls with pelagic biota (planktic foraminifera, coccolithophores and pteropods) were deposited on a distal slope.

The sea level was rising rapidly, influencing abrupt lithofacies changes in a relatively short time interval.

Planktic biota from marls point to the Middle Miocene (Badenian, Langhian) NN5 Nannoplankton Zone and M6 to M7 Planktic Foraminifera Zone; therefore drowning of the reconstructed ramp most probably cor- responds to the transgression during the Middle Miocene TB $2.43^{\text {rd }}$ order transgressive-regressive sequence as seen from planktic assemblages (foraminifera and nannoplankton) at some other localities from Croatia (e.g. Cučerje, Vejalnica, Zrin) and the Central Paratethys (e.g. Styrian Basin, Vienna Basin, Alpine-Carpathian Foredeep).

\section{Acknowledgment}

This research was initiated during the University of Zagreb financial project support "Development of geomathematical methods for the analysis of Neogene depositional environments in the Croatian part of the Pannonian Basin System" (project leader Tomislav Malvić). It was finally realized through the project support "Sedimentology and paleontology of sedimentary successions from Outer and Inner Dinarides" (project leader Alan Moro). The authors wish to thank Bojan Karaica and Renato Drempetić for the initial field prospection and Robert Koščal and Željko Ištuk from the Faculty of Science for tehnical support.

The authors fully appreciate the constructive suggestions given by both reviewers, which helped us to improve the manuscript.

\section{References}

Anthonissen, D.E. and Ogg, J.G. (compilers) (2012): Appendix 3: Cenozoic and Cretaceous biochronology of planktonic foraminifera and calcareous nannofossils. In: Gradstein, F. M., Ogg, J. G., Schmitz, M. D. and Ogg, G.M. (Eds.). The Geologic Time Scale 2012, Volume 2. Amsterdam, the Netherlands, Elsevier, 1083-1127.

Avanić, R. (1997): Analiza facijesa srednjeg miocena jugoistočnog dijela Medvednice [Facies analysis of Middle Miocene of the SE part of the Medvednica Mt.]. Unpublished MSc thesis, Faculty of Science, University of Zagreb, 1-55 (in Croatian with English abstract).

Avanić, R., Kovačić, M., Pavelić, D., Miknić, M., Vrsaljko, D., Bakrač, K. and Galović, I. (2003): The Middle and Upper Miocene Facies of Mt. Medvednica (Northern Croatia). $22^{\text {nd }}$ IAS Meeting of Sedimentology - Opatija 2003, Field Trip Guidebook, P5 167-172.

Balázs, A., Matenco, L., Magyar, I., Horváth, F. and Cloetingh, S. (2016): The link between tectonics and sedimentation in back-arc basins: New genetic constraints from the analysis of the Pannonian Basin. Tectonics, 35, 1526-1559.

Bartol, M. (2009): Middle Miocene calcareous nannoplankton of NE Slovenia (western Central Paratethys). Založba ZRC/ZRC Publishing, Ljubljana, 1-136.

Basch, O. (1981): Osnovna geološka karta SFRJ 1:100.000, list Ivanić-Grad L 33-81 [Basic Geological Map of SFRY 1:100 000, Ivanić-Grad sheet]. Geological Institute, Zagreb (1972), Federal Geological Institute, Beograd.

Basch, O. (1983): Osnovna geološka karta SFRJ 1:100.000. Tumač za list Ivanić-Grad L 33-81. [Basic Geological Map of SFRY 1:100 000, Geology of the Ivanic-Grad sheet]. 
Geological Institute, Zagreb (1980), Federal Geological Institute, Beograd, 1-66.

Basso, D., Vrsaljko, D. and Grgasović, T. (2008): The coralline flora of a Miocene maërl: the Croatian 'Litavac". Geologia Croatica, 61/2-3, 333-340.

Beavingtone-Penney, S.J. and Racey, A. (2004): Ecology of extant nummulitids and other larger benthic foraminifera. Applications in Paleoenvironmental analysis. Earth Science Review, 67, 3-4, 219-265.

Berggren, W.A., Kent, D.V, Swisher III, C.C. and Aubry. M.-P. (1995): A revised Cenozoic geochronology and chronostratigraphy. In: Berggren, W.A., Kent, D.V, Swisher, C.C., III, Aubry, M.-P' and Hardenbol, J. (eds.): Geochronology, Time Scales and Global Stratigraphic Correlation: SEPM (Society for Sedimentary Geology) Special Publication, 54, 129-212.

Böhme, M. (2003): The Miocene Climatic Optimum: evidence from ectothermic vertebrates of Central Europe. Palaeogeography, Palaeoclimatology, Palaeoecology, 195, 389-401.

Böhme, M., Ilg, A. and Winkelhofer, M. (2008): Late Miocene "washhouse" climate in Europe. Earth and Planetary Science Letters, 275, 3-4, 393-401.

Böhme, M., Winkelhofer, M. and Ilg, A. (2011): Miocene precipitation in Europe: Temporal trends and spatial gradients. Palaeogeography, Palaeoclimatology, Palaeoecology, 304, 212-218. doi:10.1016/j.palaeo.2010.09.028

Bošnjak, M. (2017): Paleoekologija i biostratigrafija badenskih (srednjomiocenskih) naslaga Medvednice na temelju mekušaca i pratećih fosilnih organizama [Paleoecology and biostratigraphy of the Middle Miocene (Badenian) deposits of the Medvednica Mt. based on mollusks and associated fossil organisms]. Unpublished PhD thesis, Faculty of Science, University of Zagreb, 1-214 (in Croatian with English abstract).

Bošnjak, M., Karaica, B., Sremac, J., Vrsaljko, D., Hajek-Tadesse, V., Gruber, A., Jeftinić, S. and Posedi, N. (2014): Middle Miocene fossil assemblages and environments in the wider area of Veternica cave (SW Medvednica Mt., NW Croatia). Acta Mineralogica-Petrographica, Abstract series $5^{\text {th }}$ International Students Geological Congress, 8, 11-11.

Bošnjak, M., Sremac, J., Vrsaljko, D., Aščić, Š. and Bosak, L. (2017): Miocene "Pteropod event" in the SW part of the Central Paratethys (Medvednica Mt., northern Croatia). Geologica Carpathica, 68, 4, 329-349.

Bown, P.R. (1998): Calcareous Nannofossil Biostratigraphy. British Micropalaeontological Society Publication Series, Chapman and Hall, Kluwer Academic, London, 1-315.

Bown, P.R. and Young, J.R. (1998): Techniques. In: Bown, P. (Ed.): Calcareous Nannofossil Biostratigraphy. Chapman and Hall, Kluwer Academic, London, 16-28.

Braga, J.C., Martin, J.M. and Riding, R. (1996): Internal structure of segments reefs: Halimeda algal mounds in the Mediterranean Miocene. Geology, 24, 1, 35-38.

Braga, J.C., Vescogni, A., Bossellini, F.R. and Aguirre, J. (2009): Coralline algae (Corallinales, Rhodophyta) in western and central Mediterranean Messinian reefs. Palaeogeography, Palaeoclimatology, Palaeoecology, 275, $1-4,113-128$.
Brlek, M., Špišić, M., Brčić, V., Mišur, I., Kurečić, T., Miknić, M., Avanić, R., Vrsaljko, D. and Slovenec, D. (2016): Mid Miocene (Badenian) transgression on Mesozoic basement rocks in the Mt. Medvednica area of northern Croatia. Facies, 62, 1-21.

Bruch, A.A., Utescher, T. and Mosbrugger, V. (2011): Precipitation patterns in the Miocene of Central Europe and the development of continentality. Palaeogeography, Palaeoclimatology, Palaeoecology, 304, 3-4, 202-211. DOI: 10.1016/j.palaeo.2010.10.002

Bucur, I.I., Saint Martin, J.P., Filipescu, S., Săsăran, E. and Pleş, G. (2011): On the presence of green algae (Dasycladales, Bryopsidales) in the Middle Miocene deposits from Podeni (western border of the Transylvanian basin, Romania). Acta Palaeontologica Romaniae, 7, 69-75.

Buhl-Mortensen, L., Mortensen, P.B., Armsworthy, Sh. and Jackson, D. (2007): Field observations of Flabellum spp. and laboratory study of the behaviour and respiration of Flabellum alabastrum. Bulletin of Marine Science, 81, 3, 543-552.

Cicha, I., Rögl, F., Rupp, C. and Čtyroká, J. (1998): Oligocene-Miocene foraminifera of the Central Paratethys. Abh. Senckenberg. Naturforsch. Gessell., 549, 1-325.

Chelaru, R. and Bucur, I.I. (2016): The taxonomy of middle Miocene red algae from the Gârbova de Sus Formation (Transylvanian Basin, Romania). Carnets de Géologie, 16, 11, 307-336.

Cloetingh, S., Maţenco, L., Bada, G., Dinu, C. and Mocanu, V. (2005): The evolution of the Carpathian-Pannonian system: Interaction between neotectonics, deep structure, polyphase orogeny and sedimentary basins in a source to sink natural laboratory. Tectonophysics, 410, 1-14.

Coletti, G. Hrabovsky, J. and Basso, D. (2016): Lithothamnion crispatum: long-lasting species of non-geniculate coralline algae (Rhodophyta, Hapalidiales). Carnets de Géologie, 16, 3, 27-41.

Ćorić, S., Pavelić, D., Rögl, F., Mandic, O., Vrabac, S., Avanić, R., Jerković, L. and Vranjković, A. (2009): Revised Middle Miocene datum for initial marine flooding of North Croatian Basins (Pannonian Basin System, Central Paratethys). Geologia Croatica, 62/1, 31-43.

De Bortoli, L. and Hladilova, Š. (2015): Taxonomical analysis of the Badenian oysters from the Moravian part of the Carpathian Foredeep (Czech Republic): a new revision. Rewiev of the Bulgarian Geological Society, 76, 2-3, 33-52.

Di Martino, E., Rösler, A., Reich, S. and Braga, J.C. (2015): A diverse patch reef from turbid habitats in the middle Miocene (East Kalimantan, Indonesia). Palaios 30, 128-149.

Eccen, A. and Çinar, M.E. (2015): Bioeroding sponge species (Porifera) in the Aegean Sea (Eastern Mediterranean). J. Black Sea/Mediterranean Environment, 21, 3, 285-306.

El-Hedeny, M. (2005): Taphonomy and Paleoecology of the Middle Miocene oysters from Wadi Sudr, Gulf of Suez, Egypt. Revue de Paléobiologie, 24, 2, 719-733.

Foster, M.S., Amado Filho, G.M., Kamenos, N.A., RiosmenaRodriguez, R. and Steller, D.L. (2013): Rhodoliths and Rhodolith Beds. Smithsonian Contributions to the Marine Sciences, 39, 143-155. 
Gain, I.E., Brewton, R.A., Reese Robillard, M.M., Johnson, K.D., Smee, D.L. and Stunz, G.W. (2017): Macrofauna using intertidal oyster reef varies in relation to position within the estuarine habitat mosaic. Marine Biology, 164, 1, 1-16. DOI:10.1007/s00227-016-3033-5

Gorjanović-Kramberger, D. (1908): Geologijska prijegledna karta Kraljevine Hrvatske-Slavonije. Tumač geologijskoj karti Zagreb (zona 22, col. XIV) (Geologische Übersichtskarte des Königreiches Kroatien-Slavonien. Erläuterungen zur geologischen Karte von Agram, Zone 22, Col XIV). Nakl. Kralj. zemalj. vlade, Odjel za unut. poslove. 1-75 (in Croatian and German).

Gradstein, F.M., Ogg, J.G., Smith, A.G., Agterberg, F.P., Bleeker, W., Cooper, R.A., Davydov, V., Gibbard, P., Hinnov, L.A., House, M.R., Lourens, L., Luterbacher, H-P., McArthur, J., Melchin, M.J., Robb, L.J., Sadler, P.M., Shergold, J., Villeneuve, M., Wardlaw, B.R., Ali, J., Brinkhuis, H., Hilgen, F.J., Hooker, J., Howarth, R.J., Knoll, A.H., Laskar, J., Monechi, S., Powell, J., Plumb, K. A., Raffi, I., Röhl, U., Sanfilippo, A., Schmitz, B., Shackleton, N.J., Shields, G.A., Strauss, H., Van Dam, J., Veizer, J., Van Kolfschoten, Th. and Wilson, D. (2004): Geologic Time Scale 2004. Cambridge University Press, $1-589$.

Grill, R. (1941): Stratigraphische Untersuchungen mit Hilfe von Mikrofaunen im Wiener Becken und den benachbarten Molasse- Anteilen. Oel und Kohle, 37, 595-602.

Hardenbol J., Thierry J., Farley M.B., Jacquin T., de Graciansky P.C. and Vail P.R. (1998): Mesozoic and Cenozoic sequence chronostratigraphic framework of European Basins. In: de Graciansky P. C., Hardenbol J., Jacquin T. and Vail P. R. (eds.): Mesozoic and Cenozoic sequence stratigraphy of European Basins. SEPM Spec. Publ. 60, 3-13.

Harzhauser, M. and Piller, W.E. (2007): Benchmark data of a changing sea - Palaeogeography, Palaeobiogeography and events in the Central Paratethys during the Miocene. Palaeogeography, Palaeoclimatology, Palaeoecology, 253, 8-31.

Haq, B.U., Hardenbol, J. and Vai, P.R. (1988): Mesozoic and Cenozoic chronostratigraphy and cycles of sea-level changes. In: Wilgus, C.K., Hastings, B.S., Kendall, C., Posamentie, H.W., Ross, C.A. and Van Wagoner, J.C. (eds.): Sea-level changes - an integrated approach. SEPM Special Publication, 42, 71-108.

Haq, B.U. and Al-Qahtani, A.M. (2005): Phanerozoic cycles of sea-level change on the Arabian Platform. GeoArabia, $10,2,127-160$.

Heidari, A., Mahboubi, A., Moussavi-Harami, R., Gonzales, L. and Ali Moallemi, S. (2013): Biostratigraphy, sequence stratigraphy, and paleoecology of the Lower-Middle Miocene of Northern Bandar Abbas, Southeast Zagros basin in south of Iran. Arabian Journal of Geosciences, 7, 18291855. DOI 10.1007/s12517-012-0803-3

Herold, N., Huber, M., Greenwood, D.R., Müller, R.D. and Seton, M. (2011): Early to middle Miocene monsoon climate in Australia. Geology, 39, 3-6.

Hohenegger J., Ćorić S., Khatun M., Pervesler P., Rögl F., Rupp Ch., Selge A., Uchman A. and Wagreich M. (2007):
Cyclostratigraphic dating in the Lower Badenian (Middle Miocene) of the Vienna Basin (Austria) - the Baden-Sooss core. International Journal of Earth Sciences (Geologische Rundschau). DOI 10.1007/s00531-007-0287-7.

Hohenegger, J., Rögl, F., Ćorić, S., Pervesler, P., Lirer, F., Roetzel, R, Schloger, R. and Stingl, K. (2009): The Styrian Basin: a key to the Middle Miocene (Badenian/Langhian) Central Paratethys transgressions. Austrian Journal of Earth Sciences, 102, 102-132.

Hohenegger, J., Ćorić, S. and Wagreich, M. (2014): Timing of the Middle Miocene Badenian Stage of the Central Paratethys. Geologica Carpathica, 65, 155-166.

Holbourn, A., Kuhnt, W., Schulz, M., Flores, J.A. and Andersen, N. (2007): Orbitally-paced climate evolution during the middle Miocene "Monterey" carbon-isotope excursion. Earth and Planetary Science Letters, 261, 534-550.

Holcová, K. and Zágoršek, K. (2008): Bryozoa, foraminifera and calcareous nannoplankton as environmental proxies of the "bryozoan event" in the Middle Miocene of the Central Paratethys (Czech Republic). Palaeogeography, Palaeoclimatology, Palaeoecology, 267, 3-4, 216-234. DOI: 10.1016/j.palaeo.2008.06.019.

Horta, P.A., Riul, P., Filho, G.M.A., Berchez, F., de Castro Nunes, J.M., Scherner, F., Pereira, S., Lotufo, T., Peres, L., Sissini, M., de Oliveira Bastos, E., Rosa, J., Munoz, P., Martins, C., Gouvêa, L., Carvalho, V., Bergstrom, E., Schubert, N., Bahia, R.G., Rodrigues, A.C., Rörig, L., Bonomi Barufi, J. and Figueiredo, M. (2016): Rhodoliths in Brazil: Current knowledge and potential impacts of climate change. Brazilian Journal of Oceanography, 64, 2, $117-135$. http://dx.doi.org/10.1590/S1679-875920160870064sp2

Horváth, F., Musitz, B., Balázs, A., Végh, A., Uhrin, A., Náador, A., Koroknai, B., Pap, N., Tóth, T. and Wórum, G. (2015): Evolution of the Pannonian basin and its geothermal resources. Geothermics, 53, 328-352.

Hoşgör, I. (2008): Presence of Crassostrea gryphoides (Schlotheim) from the lowermiddle Miocene sequence of Kahramanmaraş basin (SE Turkey); its taxonomy, paleoecology and paleogeography. Mineral Res. Expl. Bull., 136, 17-28.

Hudáčková, N., Holcová, K., Zlinská, A., Kováč, M. and Nagymarosy, A. (2000): Paleoecology and eustasy: Miocene $3^{\text {rd }}$ order cycles of relative sea-level changes in the Western Carpathian - North Pannonian Basins. Slovak Geological Magazine, 6, 95-100.

Ivanov D., Ashraf, A.R., Mosbrugger, V. and Palamarev, E. (2002): Palynological evidence for Miocene climate change in the Forecarpathian Basin (Central Paratethys, NW Bulgaria). Palaeogeography, Palaeoclimatology, Palaeoecology, 178, 1-2, 19-37.

Jansen, A.W. (1984): Type specimens of pteropod species (Mollusca, Gastropoda) described by Rolle (1861), Reuss (1867) and Kittl (1886), kept in the collection of Naturhistorisches Museum at Wienna. Meded. Werkgr. Tert. Kwart. Geol., 21/2, 61-91.

Janson, X., Van Buchem, F.S.P., Dromart, G., Eichenseer, H.T., Dellamonica, X., Boichard, R., Bonnaffe, F. and 
Eberli, G. (2010): Architeture and facies differentiation within a Middle Miocene carbonate platform, Ermenek, Mut Basin, southern Turkey. Geological Society, London, Special Publications, 329, 265-290. https://doi.org/10.1144/SP329.11

Kochansky, V. (1944): Fauna marinskog miocena južnog pobočja Medvednice (Zagrebačke gore) [Miozäne marine Fauna des südlichen Abhanges der Medvednica (Zagreber Gebirge)]. Geol. Vjestnik Hrvatskog državnog geološkog zavoda, Hrvatski državni geološki muzej, 2/3, 171-280 (in Croatian - with German summary).

Kochansky-Devidé, V. (1957): O fauni marinskog miocena i tortonskom "šliru" Medvednice (Zagrebačka gora) [Ueber die Fauna des marinen Miozäns und über den tortonischen "schlier" von Medvednica (Zagreber Gebirge)]. Geološki vjesnik, 10 (1956), 39-50 (in Croatian - with German summary).

Kranjec, V., Hernitz, Z. and Prelogović, E. (1973): Prilog poznavanju mlađih tercijarnih naslaga Medvednice (sjeverozapadna Hrvatska) [Ein Beitrag zur Kenntnis jüngerer Tertiärschichten des Medvednica-Gebirges (nordwest Kroatien)]. Geološki vjesnik, 25 (1971), 65-100 (in Croatian - with German summary).

Kroh, A. and Nebelsick, J.H. (2010): Echinoderms and OligoMiocene Carbonate Systems: Potential Applications in Sedimentology and enviromental reconstruction. Int.Assoc. Sedimentol. Spec. Publ. 42, 201-228.

Kováč, M., Andreyeva-Grigorovich, A., Bajraktarević, Z., Brzobohatý, R., Filipescu, S., Fodor, L., Harzhauser, M., Nagymarosy, A., Oszczypko, N., Pavelić, D., Rögl, F., Saftić, B., Sliva, L. and Studencka, B. (2007): Badenian evolution of the Central Paratethys Sea: paleogeography, climate and eustatic sea-level changes. Geologica Carpathica, 58, 6, 579-606.

Kováč, M., Hudáčková, N., Halásová, E., Kováčová, M., Holcová, K., Oszczypko-Clowes, M., Báldi, K., Less, G., Nagymarosy, A., Ruman, A., Klučiar, T. and Jamrich, M. (2017): The Central Paratethys palaeoceanography: a water circulation model based on microfossil proxies, climate, and changes of depositional environment. Acta Geologica Slovaca, 9, 2, 75-114.

La Perna, R., Mandic, O. and Harzhauser, M. (2017): Systematics and Palaeobiogeography of Megacardita Sacco in the Neogene of Europe (Bivalvia, Carditidae). Papers in Palaeontology, 3, 1, 111-150.

Malvić, T. and Velić, J. (2011): Neogene Tectonics in Croatian Part of the Pannonian Basin and Reflectance in Hydrocarbon Accumulations. In: Schattner, U. (ed.): New Frontiers in Tectonic Research - At the Midst of Plate Convergence. InTech, Rijeka, 215-238. DOI: 10.5772/21270

Mankiewicz, C. (1988): Occurrence and paleoecologic significance of Halimeda in Late Miocene reefs, South-eastern Spain. Coral Reefs, 6, 271-279.

Marković, F. (2017): Miocenski tufovi sjevernohrvatskoga bazena [Miocene tuffs of the North Croatian Basin]. Unpublished $\mathrm{PhD}$ Thesis, Faculty of Science. University of Zagreb, 1-170 (in Croatian with English abstract).

Martini, E. (1971): Standard Tertiary and Quartenary calcareous nannoplankton zonation. Proceedings of the II Planktonic Conference, Ed. Tecnoscienza, Roma, 739-785.
Martinuš, M., Fio, K., Pikelj, K. and Aščić, Š. (2013): Middle Miocene warm-temperate carbonates of Central Paratethys (Mt. Zrinska Gora, Croatia): paleoenvironmental reconstruction based on bryozoans, coralline red algae, foraminifera, and calcareous nannoplankton. Facies, 59/3, 481-504.

Matenco, L. and Radivojević, D. (2012): On the formation and evolution of the Pannonian Basin: Constraints derived from the structure of the junction area between the Carpathians and Dinarides. Tectonics, 31, TC6007.

Moro, A., Horvat, A., Tomić, V., Sremac, J. and Bermanec, V. (2016): Facies development and paleoecology of rudists and corals: an example of Campanian transgressive sediments from northern Croatia, northeastern Slovenia and northwestern Bosnia. Facies, 62/3, 1-25.

Pavelić, D. (2001): Tectonostratigraphic model for the North Croatian and North Bosnian sector of the Miocene Pannonian Basin System. Basin Research, 13, 359-376.

Pavelić, D. (2005): Cyclicity in the evolution of the Neogene North Croatian Basin (Pannonian Basin System). In: Mabesoone, J.M. and Neumann, V.H. (eds.): Cyclic development of sedimentary basins. Development Sedimentology, 57, 273-283.

Pavelić, D. and Kovačić, M. (2018): Sedimentology and stratigraphy of the Neogene rift-type North Croatian Basin (Pannonian Basin System, Croatia): A review. Marine and Petroleum Geology, 91, 455-469.

Pekar, S.F. and DeConto, R.M. (2006): High-resolution icevolume estimates for the early Miocene: Evidence for a dynamic ice sheet in Antarctica. Palaeogeography, Palaeoclimatology, Palaeoecology, 231, 101-109.

Perch-Nielsen, K. (1985): Cenozoic calcareous nannofossils. In: Bolli, H.M., Saunders, J.B. and Perch-Nielsen, K. (eds.): Plankton Stratigraphy. Cambridge University Press, Cambridge, 427-554.

Pezelj, Đ. (2015): Donjobadenske bentičke foraminifere lokaliteta Glavnica Gornja [Lower Badenian benthic foraminifera from Glavnica Gornja locality]. In: Mauch Lenardić, J., Hernitz Kučenjak, M., Premec Fućek, V. and Sremac, J. (eds.): International Scientific Meeting $100^{\text {th }}$ birth anniversary of Vanda Kochansky-Devidé, full member of Academy - Croatian Academy of Sciences and Arts, Zagreb, 72-72 (in Croatian).

Pezelj, Đ., Sremac, J. and Sokač, A. (2007): Palaecology of the Late Badenian foraminifera and ostracoda from the SW Central Paratethys (Medvednica Mt., Croatia). Geologia Croatica, 60/2, 139-150.

Pezelj, Đ. and Sremac, J. (2010): Sarmatske naslage lokaliteta Donje Orešje (Medvednica) [Sarmatian sediments of Donje Orešje (Medvednica Mt.)]. In: Horvat, M. (ed.): $4^{\text {th }}$ Croatian Geological Congress, Abstract Book - Croatian Geological Society, Croatian Geological Survey, Faculty of Science, Faculty of Mining, Geology and Petroleum Engineering, INA - Industrija nafte d.d., Zagreb, 102-103 (in Croatian).

Pezelj, Đ., Sremac, J. and Bermanec, V. (2016): Shallow-water benthic foraminiferal assemblages and their response to the palaeoenvironmental changes - example from the 
Middle Miocene of Medvednica Mt. (Croatia, Central Paratethys). Geologica Carpathica, 67, 329-345.

Pezelj, Đ., Sremac, J., Kovačić, M., Alagić, S. and Kampić, Š. (2017): Middle Miocene Badenian-Sarmatian sedimentary sequence in the area of Donje Orešje (Medvednica Mt., Croatia). In: Horvat, M. and Wacha, L. (eds.): Abstracts Book 7th International Workshop Neogene of Central and South-Eastern Europe, Velika, Croatian Geological Society, 46-47.

Piller, W.E., Harzhauser, M. and Mandic, O. (2007): Miocene Central Paratethys stratigraphy - current status and future directions. Stratigraphy 4, 2/3, 151-168.

Repac, M. (2017): Utjecaj dijageneze na izračun paleotemperature na temelju izotopnog sastava kućica foraminifera: primjer iz miocena Hrvatske [Diagenesis impact on paleotemperatures calculated from stable isotopes of foraminifera tests: example from Miocene in Croatia]. Unpublished Chancellor's award work, Faculty of Mining, Geology and Petroleum Engineering, University of Zagreb, 1-39 (in Croatian with English abstract).

Rögl, F. (1998): Palaeogeographic considerations for Mediterranean and Paratethys seaways (Oligocene to Miocene). Annalen des Naturhistorischen Museums in Wienn 99A, 279-310.

Rögl, F. (1999): Mediterranean and Paratethys. Facts and Hypotheses of an Oligocene to Miocene Paleogeography (Short overview). Geologica Carpathica, 50, 4, 339-349.

Rögl, F., Ćorić, S., Hohenegger, J., Pervesler, P., Roetzel, R., Scholger, R., Spezzaferri, S. and Stingl, K. (2007): Cyclostratigraphy and Transgressions at the Early/Middle Miocene (Karpatian/Badenian) Boundary in the Austrian Neogene Basins (Central Paratethys). In: Hladilová, Š., Doláková, N. and Tomanová-Petrová, P. (eds.): Scripta Geology 36. 15th Conference on Upper Tertiary, Proceedings and Extended Abstracts. - 1. vyd. Masaryk University, Faculty of Science, 7-13.

Rögl, F., Ćorić, S., Harzhauser, M., Jimenez-Moreno, G., Kroh, A., Schultz, O., Wessely, G. and Zorn, I. (2008): The Middle Miocene Badenian stratotype at Baden-Sooss (Lower Austria). Geologica Carpathica, 59, 5, 367-374.

Sant, K., de Leeuv, A., Chang, L., Czapowski, G., Gasiewicz, A. and Krijgsman, W. (2015): Paleomagnetic analyses on Badenian-Sarmatian drill cores from the north Carpathian foredeep (Middle Miocene, Poland). Biuletyn Państwowego Instytutu Geologicznego, 461, 179-192.

Sant, K., Palcu, D.V., Mandic, O. and Krijgsman, W. (2017): Changing seas in the Early-Middle Miocene of Central Europe: a Mediterranean approach to Paratethyan stratigraphy. Terra Nova, 29, 273-281.

Sarkar, S. (2015): Upper Pliocene heterozoan assemblage from the Guitar Formation of Car Nicobar Island, India: paleoecological implications and taphonomic signatures. Palaeobiodiversity and Palaeoenvironments, 1-17. DOI. 10.1007/s12549-015-0214-z.

Shackleton, N.J. and Kennett, J.P. (1975): Paleotemperature history of the Cenozoic and initiation of the Antarctic glaciation: oxygen and carbon isotopic analyses in DSDP Sites 277, 279 and 281. In: Kennett, J. P. and Houtz, R.E. (eds.): Init. Rep. DSDP, 29, 743-755.
Sremac, J., Bošnjak Makovec, M., Vrsaljko, D., Karaica, B., Tripalo, K., Fio Firi, K., Majstorović Bušić, A. and Marjanac, T. (2016): Reefs and bioaccumulation in the Miocene deposits of the North Croatian Basin - Amazing diversity yet to be described. The Mining-Geology-Petroleum Engineering Bulletin, 10, 19-29.

Studencka, B. (1986): Bivalves from the Badenian (Middle Miocene) marine sandy facies of southern Poland. Palaeontologia Polonica, 47, 3-128.

Šikić, K., Basch, O. and Šimunić, A. (1978): Osnovna geološka karta SFRJ 1:100.000, list Zagreb, L 38-80 [Basic Geological Map of SFRY 1:100 000, Zagreb sheet]. Geological Institute, Zagreb, Federal Geological Institute, Beograd (1977).

Šikić, K., Basch, O. and Šimunić, A. (1979): Osnovna geološka karta SFRJ, list Zagreb 1:100.000. Tumač za list Zagreb, L 38-80 [Basic Geological Map of SFRY 1:100 000, Geology of the Zagreb sheet]. 1-81, Geological Institute, Zagreb (1972) Savezni geološki zavod, Beograd (in Croatian).

Tomljenović, B. (2002): Strukturne značajke Medvednice i Samborskog gorja [Structural Characteristics of Medvednica and Samoborsko Gorje Mountains]. Unpublished Ph. D. thesis, Faculty of Mining, Geology and Petroleum Engineering, University of Zagreb, 1-208 (in Croatian with English abstract).

Tomljenović, B., Csontos, L., Márton, E. and Márton, P. (2008): Tectonic evolution of the northwestern Internal Dinarides as constrained by structures and rotation of Medvednica Mountains, North Croatia. In: Siegesmund, S., Fügenschuh, B. and Froitzheim, N. (eds.): Tectonic Aspects of the Alpine-Dinaride-Carpathian System. Geological Society, London, Special Publications, 298, 145-167.

Tripalo, K., Japundžić, S., Sremac, J. and Bošnjak, M. (2016): First record of Acanthuridae (surgeonfish) from the Miocene deposits of the Medvednica Mt. Geologia Croatica, 69/2, 201-214. DOI: 10.4154/gc.2016.15

Tripalo, K. (2017): Miocenski biolititi istočnog dijela Medvednice Medvednice [Miocene Biolithites from eastern side of Medvednica Mt.]. Unpublished diploma thesis, Faculty of Science, University of Zagreb, 1-66 (in Croatian with English abstract).

Velić, I. and Vlahović, I. (eds.). (2009). Explanatory notes for the geological map of the Republic of Croatia in 1:300.000 scale.Croatian Geological Institute, 1-141, Zagreb (in Croatian).

Vrsaljko, D., Pavelić, D., Miknić, M., Brkić, M., Kovačić, M., Hećimović, I., Hajek-Tadesse, V., Avanić, R. and Kurtanjek, N. (2006): Middle Miocene (Upper Badenian/Sarmatian) Palaeoecology and Evolution of the Environments in the Area of Medvednica Mt. (North Croatia). Geologia Croatica, 59/1, 51-63.

Wade, B.S., Pearson, P.N., Berggren W.A. and Pälike, H. (2011): Review and revision of Cenozoic tropical planktonic foraminiferal biostratigraphy and calibration to the geomagnetic polarity and astronomical time scale. EarthScience Reviews, 104, 111-142.

Wilson, M.E.J. and Wecsei, A. (2005): The apparent paradox of abundant foramol facies in low latitudes: their environ- 
mentl significance and effect on platform development. Earth-Science Reviews, 69, 133-168.

Zachos, J., Pagani, M., Sloan, E., Thomas, E. and Billups, K. (2001): Trends, Rhytms, and Aberrations in Global Climate 65 Ma to Present. Science, 292, 686-693.

Zágoršek, K. (2015): Paleobiogeography of selected taxa of Miocene Bryozoa. Hantkeniana, 10, 125-134.

Zágoršek, K., Holcová, K., Nehyba, S., Kroh, A. and Hladilová, S̆. (2008a): The invertebrate fauna of the Middle Miocene (Lower Badenian) sediments of Kralice nad Oslavou (Central Paratethys, Moravian part of the Carpathian Foredeep). Bulletin of Geosciences, 84, 3, 465-496. DOI: 10.3140/bull.geosci.1078.

Zágoršek, K., Holcová, K. and Třasoň, T. (2008b): Bryozoan event from Middle Miocene (Early Badenian) lower neritic sediments from the locality Kralice nad Oslavou (Cen- tral Paratethys, Moravian part of the Carpathian Foredeep). International Journal of Earth Sciences 97, 835-850.

Zágoršek, K., Filipescu, S. and Holcová, K. (2010): New Middle Miocene bryozoan from Gârbova de Sus (Romania) and their relationship to the sedimentary environment. Geologica Carpathica, 61, 495-512. DOI: 10.2478/ v10096-010-0031- 2 .

\section{Internet sources:}

Google Earth (assessed in November, 2017)

URL: http://www.azu.hr/en-us/E-P/Geological-overview-onshore (assessed in November, 2017)

URL: http://ina.tmsoc.org/Nannotax3/index.php?dir=Coccolithophores (assessed in April, 2016)

\section{SAŽETAK}

\section{Srednjomiocenska potopljena rampa u okolici Marije Bistrice (sjeverna Hrvatska)}

Uz cestu Marija Bistrica - Adamovec, nedaleko od raskrižja prema Lazu, može se na izdancima pratiti slijed srednjomiocenskih naslaga. U bazi slijeda vide se polimiktni, klastpotporni do matrikspotporni konglomerati. Valutice uglavnom odgovaraju sastavu okolnih stijena, a vezivo predstavlja koralinacejski bioklastični vekston. Sekundarni nalazi velikih oštriga upućuju na moguća ostrižišta, vjerojatno nedaleko od riječnoga ušća. U zaštićenim lagunama stvarali su se rodoliti malih dimenzija, živjele su halimede i nježni, razgranjeni mahovnjaci i puževi. U oligotrofnim uvjetima alge su učestalije od mahovnjaka. Zbog isparavanja povećana je koncentracija i kristalizacija kalcijeva karbonata, koji je cementirao bioklaste. Oko nekih su bioklasta vidljive kortoidne ovojnice, a sediment je tipa grejnston. Rodolitno-briozojske biokonstrukcije nastajale su najviše u plitkoj potplimnoj zoni, najvjerojatnije na dubinama od 20 do $30 \mathrm{~m}$. Mjestimice su izgrađivale barijere između laguna i otvorenoga mora. One se nisu uspjele sačuvati in situ, već kao fragmenti u bioklastičnim taložinama padine. Na strmijim padinama pokazuju mikrostrukturu floutstona. Sadržavaju velike briozojske kolonije i bioerodirane solitarne koralje, kakvi su mogli živjeti u nešto dubljemu okolišu, vjerojatno između 30 i 75 m, uz nešto veću količinu nutrijenata. U vrhu slijeda, samo desetak metara iznad konglomerata, leže lapori s pučinskim organizmima (kalcitičnim nanoplanktonom, planktonskim i malim bentičkim foraminiferama i planktonskim puževima, pteropodima), kakvi su obično taloženi na distalnim padinama. Morska je razina brzo rasla, što je dovelo do naglih promjena u istraženome taložnom prostoru. Planktonski organizmi iz lapora upućuju na NN5 nanoplanktonsku zonu srednjega badena, pa se tonjenje rampe može povezati s početkom transgresivno-regresivnoga ciklusa TB 2.4.

\section{Ključne riječi:}

langij, transgresija, paleoekologija, biostratigrafija, Medvednica

\section{Authors' contribution}

Jasenka Sremac was responsible for the research idea and planning, field work, palaeoecological interpretations and presentation of results. She was mentoring K. Tripalo and M. Repac. Kristina Tripalo collected in the field, prepared thin sections and interpreted the samples of red algae and coralgal lithofacies during her diploma research. Marko Repac collected in the field, prepared and interpreted the marl samples and microfossils for the Chancellor's Award. Marija Bošnjak collected in the field, prepared and determined planktic and benthic mollusks and was involved in the interpretation of facies and biostratigraphical conclusions. Davor Vrsaljko conducted field work, supervised the macrofossil determination and interpreted transgressive-regressive sequences. Tihomir Marjanac conducted field work and interpreted lithofacies. Alan Moro conducted field work, geological column and research of Cretaceous pebbles. Borna Lužar Oberiter conducted field work, prepared and interpreted basal clastites. Karmen Fio Firi, as a co-mentor to M. Repac, was involved in research of marls and isotope analyses. Šimun Aščić provided nannoplankton analyses from marls. 